January 2019

\title{
Article III, Judicial Restraint, and This Supreme Court
}

Joseph S. Diedrich

Husch Blackwell LLP

\section{Recommended Citation}

Joseph S. Diedrich, Article III, Judicial Restraint, and This Supreme Court, 72 SMU L. REV. 235 (2019) https://scholar.smu.edu/smulr/vol72/iss2/9

This Article is brought to you for free and open access by the Law Journals at SMU Scholar. It has been accepted for inclusion in SMU Law Review by an authorized administrator of SMU Scholar. For more information, please visit http://digitalrepository.smu.edu. 


\title{
Article III, Judicial Restraint, And This Supreme Court
}

\author{
Joseph S. Diedrich*
}

\begin{abstract}
Article III of the U.S. Constitution establishes a federal judiciary with powers and functions separate and distinct from the other branches. During its October 2017 Term, the U.S. Supreme Court decided three cases that turned on an interpretation of Article III power: Patchak v. Zinke, Oil States Energy Services v. Greene's Energy Group, and Gill v. Whitford.

This Article argues that in each of those three cases, a majority of the Court coalesced around a unifying principle of judicial restraint. By "judicial restraint," this Article refers to the principle that the judiciary should respect and defer to the elected branches. In cases interpreting Article III, then, judicial restraint instructs the Court to refrain from asserting its own power and to instead decide in favor of another branch's power. In Patchak, Oil States, and Gill, despite stark doctrinal differences, the Court refrained from asserting the judiciary's own power and chose instead to exercise judicial restraint. Such restraint can thus be viewed as a common undercurrent guiding the Court's Article III jurisprudence.

At the same time, simply comparing the Court's holdings at the case level overlooks important nuances. Even though a judicially restrained holding commanded a majority in all three cases, each of those majorities was differently constituted. To that end, this Article also examines the Justices' individual approaches to Article III jurisprudence. This examination reveals, perhaps unsurprisingly, that other principles influence certain Justices and that certain Justices, at times, vote inconsistently. Nonetheless, each Justice has, to a greater or lesser extent, embraced the principle of judicial restraint in Article III cases. Even accounting for the Justices' individual differences, this Article ultimately concludes that holdings consistent with judicial restraint will likely continue to command a majority in Article III cases, at least for the foreseeable future.
\end{abstract}

\section{TABLE OF CONTENTS}

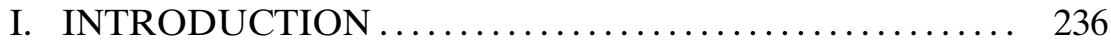

II. THE THREE 2017 TERM CASES ................. 238

* Joseph S. Diedrich is a litigation and appellate attorney with Husch Blackwell LLP. He received his Juris Doctor from the University of Wisconsin Law School summa cum laude, Order of the Coif. Special thanks to Elizabeth Stephens, Jeffrey McIntyre, and Eric McLeod for their assistance and support. All opinions expressed in this Article are the author's alone. 
A. Patchak v. Zinke .......................... 238

B. Oil States Energy Services v. Greene's ENERGy

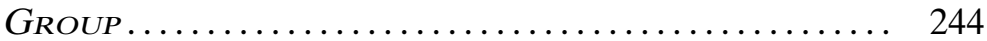

C. Gill v. WhitFORD........................ 248

III. THE CASES: DISCOVERING JUDICIAL RESTRAINT

AS A UNIFYING PRINCIPLE ................. 252

IV. THE JUSTICES: MAKING SENSE OF INDIVIDUAL

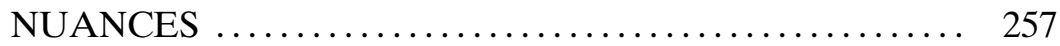

A. Justice Alito ............................... 258

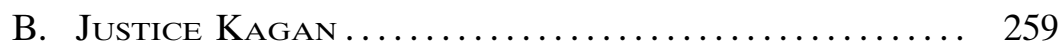

C. Justice Breyer ................................. 260

D. Justice Thomas ............................. 261

E. Justice Ginsburg ........................... 262

F. Chief Justice Roberts ............................ 264

G. Justice Gorsuch .......................... 268

H. Justice Sotomayor.......................... 270

V. CONCLUSION ............................. 273

\section{INTRODUCTION}

RTICLES I, II, and III of the United States Constitution estab$\triangle$ lish three branches of government, each endowed with a sepa1 rate form of governmental power: legislative, executive, and judicial, respectively. Under Article III, the "judicial Power of the United States" is "vested in one supreme Court, and in such inferior Courts as the Congress may from time to time ordain and establish."1 The "judicial power" granted to the federal judiciary under Article III includes the power of judicial review and installs the U.S. Supreme Court as the "ultimate interpreter of the Constitution." 2 The Supreme Court thus finds itself possessing a peculiar authority to determine the constitutional contours of its own power, as well as the power of the entire federal judiciary.

From time to time, the Supreme Court is called upon to exercise that peculiar authority. During its October 2017 Term, the Court's interpretation of Article III determined the outcome of three cases. ${ }^{3}$ The first was Patchak v. Zinke ${ }^{4}$ in which the Court analyzed abstract separation of powers questions and interpreted a principle, announced over fourteen decades ago in United States v. Klein, ${ }^{5}$ that Congress cannot decide pend-

1. U.S. Const. art. III, $\S 1$.

2. Baker v. Carr, 369 U.S. 186, 211 (1962); see also Cooper v. Aaron, 358 U.S. 1, 18 (1958); Marbury v. Madison, 5 U.S. (1 Cranch) 137, 177 (1803); Randy E. Barnett, The Original Meaning of Judicial Power, 12 Sup. CT. Econ. Rev. 115, 138 (2004).

3. Article III issues also arose in other cases decided during the 2017 Term, such as Trump v. Hawaii, 138 S. Ct. 2392 (2018). This Article, however, focuses on cases that were ultimately decided on Article III grounds.

4. 138 S. Ct. 897 (2018) (plurality opinion).

5. 80 U.S. (13 Wall.) 128, 145-47 (1872). 
ing cases. The second case, Oil States Energy Services v. Greene's Energy Group ${ }^{6}$ examined whether Congress had constitutionally delegated the adjudication of patent validity to a non-Article III tribunal under the "public-rights" doctrine. And the third case, Gill v. Whitford, ${ }^{7}$ saw the Court apply Article III standing doctrine in the context of a partisangerrymandering lawsuit.

The outcome in all three cases turned on how the Court interpreted the scope of the judiciary's own power under Article III. United by that basic commonality, the three cases present at least two related questions. First, what do the outcomes in each case share in common, even across the respective Article III sub-doctrines of the Klein principle, the publicrights doctrine, and standing doctrine? And second, given how the composition of the majority differed in each case, how does each individual Justice approach Article III?

This Article addresses both questions. Part II presents an in-depth summary of each of the three Article III cases the Court decided during its October 2017 Term, including concurring and dissenting opinions. While all three cases touched broadly on Article III and the separation of powers, each concentrated more specifically on a discrete Article III sub-doctrine. With those sub-doctrine-specific concentrations in mind, Part III seeks to extract a unifying principle that explains and underlies the outcomes in all three cases. Drawing on the scholarship of Judge Richard Posner and others, Part III concludes that the concept of judicial restraint supplies that unifying principle and acts as a common thread across Patchak, Oil States, and Gill. Despite how each case featured a different Article III sub-doctrine, and despite how each holding commanded a differently constituted majority, a majority of the Court in each case nonetheless united around an outcome consistent with judicial restraint.

Still, as mentioned, the Justices constituting the majorities-and the plurality in Patchak-differed in each of the three cases. This differentiation suggests that judicial restraint alone cannot fully explain the respective Justices' individual voting behavior. To that end, Part IV drills the analysis down to the level of the Justices. It examines in detail the votes, as well as the underlying reasoning, of each Justice in Patchak, Oil States, Gill, and other recent Article III cases. Part IV then comments on each Justice's votes across the respective Article III sub-doctrines, examines the consistency of each Justice's votes over time, compares each Justice's votes to the other Justices', and dissects each Justice's votes and reasoning as they relate to judicial restraint. Ultimately, this exercise reveals how this Court's view on judicial restraint as an institution is, perhaps axiomatically, made up of each Justice's individual approach toward the principle.

Finally, Part V concludes by reiterating how, notwithstanding the Justices' individual nuances, holdings marked by judicial restraint have be-

6. 138 S. Ct. 1365 (2018).

7. 138 S. Ct. 1916 (2018). 
come the norm for this Supreme Court in Article III cases. Based on that observation, this Article cautiously forecasts that the Court will continue to decide Article III cases in a matter consistent with judicial restraint, at least for the foreseeable future.

\section{THE THREE 2017 TERM CASES}

\section{A. PATCHAK V. ZINKE}

The first of the three Article III cases decided by the Court during its October 2017 Term was Patchak v. Zinke. ${ }^{8}$ In Patchak, the Match-E-BeNash-She-Wish Band of Pottawatomi Indians (Band) sought to build a casino in southwestern Michigan on a tract of land known as the Bradley Property. As a necessary step in the casino approval process, the Secretary of the Interior took the Bradley Property into trust for the Band. ${ }^{9}$

David Patchak (Patchak) owned land near the Bradley Property. ${ }^{10}$ "Fearing an 'irreversibl[e] change [to] the rural character of the area""11 and not wanting a casino in his backyard, Patchak sued under the Administrative Procedure Act. He claimed the Secretary lacked the authority to take the Bradley Property into trust. ${ }^{12}$

While Patchak's suit was pending in district court, ${ }^{13}$ Congress passed, and the President signed, the Gun Lake Trust Land Reaffirmation Act (Gun Lake Act). ${ }^{14}$ The relevant section $(\S 2)$ provides, in part:

(a) IN GENERAL.-The land taken into trust by the United States for the benefit of the Match-E-Be-Nash-She-Wish Band of Pottawatomi Indians and described in the final Notice of Determination of the Department of the Interior (70 Fed.Reg. 25596 (May 13, 2005)) is reaffirmed as trust land, and the actions of the Secretary of the Interior in taking that land into trust are ratified and confirmed.

(b) NO CLAIMS.--Notwithstanding any other provision of law, an action (including an action pending in a Federal court as of the date of enactment of this Act) relating to the land described in subsection (a) shall not be filed or maintained in a Federal court and shall be promptly dismissed. ${ }^{15}$

Based on $\S 2(b)$, the district court granted summary judgment and dis-

8. Patchak, 138 S. Ct. 897

9. Id. at 903.

10. Id.

11. Id. at 916 (Roberts, C.J., dissenting).

12. Id. at 903 (plurality opinion).

13. That is, pending in district court for a second time. Id. at 904. Patchak's lawsuit rose to the U.S. Supreme Court once before on the Secretary's initial challenges: sovereign immunity and prudential standing. See Match-E-Be-Nash-She-Wish Band of Pottawatomi Indians v. Patchak, 567 U.S. 209, 212 (2012). The Supreme Court ruled that "Patchak had standing and the Secretary lacked immunity," and that "Patchak's suit may proceed." Patchak, 138 S. Ct. at 904 (internal quotation marks omitted). The Court remanded. Id.

14. Gun Lake Trust Land Reaffirmation Act, Pub. L. No. 113-179, 128 Stat. 1913 (2014).

15. Id. 
missed Patchak's lawsuit for lack of subject matter jurisdiction. ${ }^{16}$ The Court of Appeals for the D.C. Circuit affirmed on the same grounds. ${ }^{17}$ The U.S. Supreme Court then granted certiorari on a single issue: whether $\S 2(b)$ of the Gun Lake Act violates separation of powers principles under the U.S. Constitution. ${ }^{18}$

A fractured Supreme Court held that $\S 2$ (b) does not violate the Constitution. ${ }^{19}$ No single line of reasoning convinced a majority. Four Justices-Thomas, Breyer, Alito, and Kagan-concluded that $\S 2$ (b) was constitutional because it did not violate Article III or the separation of powers. ${ }^{20}$ Writing for the plurality, Justice Thomas began by recognizing that "[ $\mathrm{t}]$ he Constitution creates three branches of Government and vests each branch with a different type of power."21 To that end, "[t]he separation of powers ... prevents Congress from exercising the judicial power."22

Drawing on past precedent, the plurality declared that "Congress violates Article III when it 'compel[s] . . . findings or results under old law," "23 but "does not violate Article III when it 'changes the law." 24 "One way that Congress can cross the line from legislative power to judicial power is by 'usurp[ing] a court's power to interpret and apply the law to the [circumstances] before it'"25_-for example, by enacting a statute that says, "[i]n Smith v. Jones, Smith wins."26

The plurality ultimately concluded that $\S 2(\mathrm{~b})$ of the Gun Lake Act "changes the law" and therefore does not violate the separation of powers. ${ }^{27}$ To reach that conclusion, however, the plurality first interpreted $\S 2$ (b) as a jurisdiction-stripping provision. According to the plurality, $\S 2$ (b) "uses jurisdictional language," 28 noting:

It [1] states that an "action" relating to the Bradley Property "shall not be filed or maintained in a Federal court"[;] .. . [2] imposes jurisdictional consequences: Actions relating to the Bradley Property "shall be promptly dismissed"[;] . . . [3] has no exceptions[;] [and 4] applies "[n]otwithstanding any other provision of law," including the

16. Patchak v. Jewell, 109 F. Supp. 3d 152, 156 (D.D.C. 2015).

17. Patchak v. Jewell, 828 F.3d 995, 1007-08 (D.C. Cir. 2016).

18. Patchak, 138 S. Ct. at 904. Patchak had presented other challenges to the Gun Lake Act, too, but the Court granted certiorari only to review his separation of powers challenge. See id.; Petition for Writ of Certiorari at 2, Patchak, 138 S. Ct. 897 (No. 16-498), 2016 WL 10805559 , at $* 2$.

19. Patchak, 138 S. Ct. at 904.

20. Id. at 911 .

21. Id. at 904

22. Id. at 905 .

23. Id. (alteration in original) (quoting Robertson v. Seattle Audubon Soc., 503 U.S. 429, 438 (1992)).

24. Id. (alteration in original) (quoting Plaut v. Spendthrift Farm, Inc., 514 U.S. 211, 218 (1995))

25. Id. (alteration in original) (quoting Bank Markazi v. Peterson, 136 S. Ct. 1310, 1323 (2016)).

26. Id. (quoting Bank Markazi, $136 \mathrm{~S}$. Ct. at 1323 n.17).

27. $I d$.

28. Id. at 905 . 
general grant of federal-question jurisdiction, 28 U.S.C. $§ 1331 .{ }^{29}$

While conceding that "§ 2(b) does not use the word 'jurisdiction,", 30 the plurality asserted that $\S 2$ (b) nonetheless "uses language similar to other statutes that this Court has deemed jurisdictional." 31 The plurality further reasoned that $\S 2$ (b) "cannot plausibly be read as anything else" other than a jurisdiction-stripping statute, in part because it "does not identify 'an element of [the] plaintiff's claim for relief' or otherwise define its "substantive adequacy.", 32

Characterizing $\S 2(\mathrm{~b})$ as a jurisdiction-stripping statute was essential for the plurality, because under prior case law, such statutes " chang[e] the law' for the purpose of Article III." ${ }^{33}$ Indeed, a change in jurisdiction is a change in law, "just as much as other exercises of Congress' legislative authority." 34 Jurisdiction-stripping statutes, the plurality explained, "do not involve 'the exercise of judicial power' or 'legislative interference with courts in the exercising of continuing jurisdiction." 35 Ultimately, because $\S 2(b)$ "changes the law," it does not "infringe on the judicial power." 36

The plurality also rejected Patchak's and the dissent's arguments based on United States v. Klein, ${ }^{37}$ a Reconstruction Era case holding that Congress had unconstitutionally encroached on the judiciary's power by passing an outcome-determining statute. ${ }^{38}$ While conceding that $\S 2(\mathrm{~b})$ 's " 'relating to' standard effectively guaranteed that Patchak's suit would be dismissed," the plurality nevertheless maintained that it "does not flatly direct federal courts to dismiss lawsuits under old law. It creates new law for suits relating to the Bradley Property ...." ${ }^{39}$ In this regard, the plurality found support in, and built upon, the Court's decision two years ear-

29. Id. (internal citations omitted).

30. $I d$.

31. Id. (citing Gonzalez v. Thaler, 565 U.S. 134, 142 (2012); then citing Keene Corp. v. United States, 508 U.S. 200, 208-09 (1993); and then citing Weinberger v. Salfi, 422 U.S. 749, $756(1975))$.

32. Id. at 906 (alteration in original) (quoting Arbaugh v. Y \& H Corp., 546 U.S. 500, $516(2006))$.

33. Id. (alteration in original) (quoting Plaut v. Spendthrift Farm, Inc., 514 U.S. 211, $218(1995))$.

34. Id. Under the generally accepted "lesser-included" reading of Article III, "Congress's greater power to create lower federal courts includes its lesser power to 'limit the jurisdiction of those Courts.' 'Id. (quoting United States v. Hudson, 11 U.S. (7 Cranch) 32, $33(1812))$.

35. Id. at 907 (citing Ex parte McCardle, 74 U.S. (7 Wall.) 506, 514 (1869)).

36. Id. at 908 . While "understand[ing] why Patchak would view the Gun Lake Act as unfair," the plurality found comfort in how "[n]othing on the face of $\S 2$ (b) is limited to Patchak's case .... Instead, the text extends to all suits 'relating to' the Bradley Property." Id. at 910 .

37. 80 U.S. (13 Wall.) 128, 145-48 (1872). See generally William D. Araiza, The Once and (Maybe) Future Klein Principle, 74 Wash. \& Lee L. Rev. Online 383 (2018); Evan C. Zoldan, The Klein Rule of Decision Puzzle and the Self-Dealing Solution, 74 WASH. \& LEE L. Rev. 2133 (2017).

38. Patchak, 138 S. Ct. at $908-11$.

39. Id. at 908 . 
lier in Bank Markazi v. Peterson. ${ }^{40}$ The Bank Markazi Court rejected a separation of powers challenge to a statute similar to the Gun Lake Act, insofar as the statute "changed the law" while also prescribing rules for a very narrow class of pending cases. ${ }^{41}$

Justice Breyer, who joined in Justice Thomas's plurality opinion, also filed his own concurrence. ${ }^{42} \mathrm{He}$ emphasized that reading $\$ 2(\mathrm{a})$ of the Gun Lake Act in conjunction with $\S 2$ (b) supports the plurality's conclusion that the Act does not violate the separation of powers. ${ }^{43}$ Section 2(a) "'reaffirm[s]" . . the status of the Bradley Property 'as trust land," thereby eliminating the substantive basis of Patchak's suit. ${ }^{44}$ Section 2(b), then, merely embellishes $\S 2(a)$; it "dot[s] all the i's by adding that federal courts shall not hear cases challenging the land's trust status." 45

Justice Ginsburg, joined by Justice Sotomayor, concurred in the judgment, reasoning that $\S 2$ (b) is most naturally read as reinstating sovereign immunity. ${ }^{46}$ Patchak brought a claim under the Administrative Procedure Act, which waives the federal government's sovereign immunity. ${ }^{47}$ This voluntary consent-to-suit can be "withdrawn 'at any time," "48 including in pending litigation. ${ }^{49}$ For Ginsburg, the language of $\S 2(\mathrm{~b})$ withdrew-in the specific circumstances covered by $\S 2$ (b) - the APA's sovereign-immunity waiver. ${ }^{50}$ In other words, "Congress acted effectively to displace the APA's waiver of immunity for suits against the United States with a contrary command applicable to the Bradley Property ...."51 This conclusion decided the case for Ginsburg and permitted her to "avoid[] the separation of powers concerns raised . . . about jurisdiction stripping." 52 That is, Ginsburg's concurring opinion did not answer the Article III question raised in the case one way or the other. Counting Ginsburg's concurrence in the judgment, a majority of the Court voted to uphold the Gun Lake Act.

In addition to joining in Justice Ginsburg's opinion, Justice Sotomayor also filed a separate opinion concurring in the judgment. ${ }^{53}$ Beyond reiter-

40. 136 S. Ct. 1310 (2016).

41. Id. at $1324-29$.

42. Patchak, 138 S. Ct. at 911-12 (Breyer, J., concurring).

43. Id. at 911 . Notably, at the Supreme Court, Patchak challenged the constitutionality of only $\S 2(\mathrm{~b})$.

44. Id. (alteration omitted).

45. $I d$.

46. Id. at 912-13 (Ginsburg, J., concurring).

47. Id. at 912 .

48. Id. (quoting Lynch v. United States, 292 U.S. 571, 581 (1934)).

49. Id. (citing District of Columbia v. Eslin, 183 U.S. 62, 65-66 (1901)).

50. Id. at 913. To further bolster her argument, Ginsburg noted that the language Congress employed in the Gun Lake Act (any "action ... relating to the [Bradley Property] . . . shall be promptly dismissed") is the mirror image of the APA's immunity waiver, which instructs that suits "against the United States" for declaratory or injunctive relief "shall not be dismissed." Id. (alteration in original) (emphasis in original) (quoting 5 U.S.C. $§ 702$ (2012)).

51. Id.

52. Id. at 914 (Sotomayor, J., concurring).

53. See id. at 913-14. 
ating her agreement with Ginsburg, Sotomayor expressly

agree[d] with the dissent that Congress may not achieve through jurisdiction stripping what it cannot permissibly achieve outright, namely, directing entry of judgment for a particular party ... [and] also agree[d] that an Act that merely deprives federal courts of jurisdiction over a single proceeding is not enough to be considered a change in the law and that any statute that portends to do so should be viewed with great skepticism. ${ }^{54}$

Chief Justice Roberts, joined by Justices Kennedy and Gorsuch, dissented. Comparing $\S 2(\mathrm{~b})$ of the Gun Lake Act to the hypothetical "Smith wins" statute, ${ }^{55}$ Roberts described $\S 2(\mathrm{~b})$ as a "very real statute that dictates the disposition of a single pending case," which, if upheld, would "cede unqualified authority to the Legislature to decide the outcome of such a case." 56 In short, § 2(b) violates Article III and separation of powers principles.

The Chief Justice began his dissent by describing how colonial legislatures before and during the Founding Era often functioned as courts of equity and decided the merits of controversies between parties. ${ }^{57}$ Madison decried such action, fearing that legislatures were "drawing all power into [their] impetuous vortex." 58 Against this backdrop, the Founders took the "innovative step" of structuring the federal government with a truly independent judiciary, as set forth in Article III. ${ }^{59}$

Article III thus serves dual, reflexive purposes. On the one hand, it grants power to one branch-the judiciary-to exercise judicial power. On the other hand, it limits the power of the other two branches to likewise operate in the judiciary's orbit. ${ }^{60}$ Klein recognized this principle, as Roberts explained:

We first enforced that rule in United States $v$. Klein, when the Radical Republican Congress passed a law targeting suits by pardoned Confederates. Although this Court had held that a pardon was proof of loyalty and entitled claimants to damages for property seized by the Union, Congress sought to block Confederate supporters from re-

54. Id. at 913 .

55. Id. at 914 (Roberts, C.J., dissenting) (quoting Bank Markazi v. Peterson, 136 S. Ct. 1310, 1323 n.17 (2016)); see supra note 26 and accompanying text.

56. Patchak, 138 S. Ct. at 914 (Roberts, C.J., dissenting).

57. Id. at 914-15 (citing John F. Manning, Response, Deriving Rules of Statutory Interpretation from the Constitution, 101 Colum. L. Rev. 1648, 1662 (2001)).

58. Id. at 914 (alteration in original) (quoting The FEDERAlist No. 48, at 309 (James Madison) (Clinton Rossiter ed., 1961)).

59. Id. at 915.

60. See id. (citing Fletcher v. Peck, 10 U.S. (6 Cranch) 87, 136 (1810)). Chief Justice Roberts's opinion for the Court in Stern v. Marshall further explains Article III's functions: "As its text and our precedent confirm, Article III is an 'inseparable element of the constitutional system of checks and balances' that 'both defines the power and protects the independence of the Judicial Branch.'” 564 U.S. 462, 482-83 (2011) (quoting N. Pipeline Constr. Co. v. Marathon Pipe Line Co., 458 U.S. 50, 58 (1982) (plurality opinion)). Moreover, "Article III protects liberty not only through its role in implementing the separation of powers, but also by specifying the defining characteristics of Article III judges," including, most prominently, their tenure and salary protection. $I d$. at $483-84$. 
ceiving such compensation. It therefore enacted a statute barring rebels from using a pardon as evidence of loyalty, instead requiring the courts to dismiss for want of jurisdiction any suit based on a pardon. This Court declared the law unconstitutional. Congress, in addition to impairing the President's pardon power, had "prescribe[d] rules of decision to the Judicial Department . . . in cases pending before it." The Court accordingly held that the statute "passed the limit which separates the legislative from the judicial power." 61

Bank Markazi, according to Roberts, maintained Klein's essential limitation on Congress's ability to encroach on Article III power. ${ }^{62}$

Roberts next turned to the "stark" facts of the Patchak case, focusing on the reality at the time Congress passed the Gun Lake Act. ${ }^{63}$ Despite its neutral-sounding language, "no other suits relating to the Bradley Property were pending" when Congress passed that Act. ${ }^{64}$ Whatever its efforts at similar legislation in the past, Congress had never attempted anything as "brazen" or that "[went] so far" as the Gun Lake Act. ${ }^{65}$ Even the statute in Bank Markazi, which Roberts had objected to on the same grounds, had left some room for actual judicial decision-making. ${ }^{66}$ Section 2(b), by contrast, "targets a single pending case," and notwithstanding "formal language" that could "theoretically suggest a broader application, .. . practical[ly] operat[es]" to apply only to Patchak's suit. ${ }^{67}$

The Chief Justice squarely rejected the plurality's reading of $\S 2$ (b) as jurisdictional. ${ }^{68}$ As he pointed out, neither the "title, headings, [n]or text of the Act" use the word "jurisdiction" or "specif[y] that the statute is jurisdictional."69 That fact held "special significance" for Roberts, because the Court in recent cases has attempted to "rein in "profligate use of the term" " and to "treat[ ] statutory limitations as nonjurisdictional unless Congress 'clearly states' otherwise."70 Again analogizing to Klein, Roberts would have held "that Congress exercises the judicial power

61. Patchak, 138 S. Ct. at 915 (alterations in original) (citations omitted) (quoting United States v. Klein, 80 U.S. (13 Wall.) 128, 146 (1872)).

62. Id. at 916. That said, Chief Justice Roberts also thought the statute in Bank Markazi went too far and violated Klein's limitation on legislative power. See Bank Markazi v. Peterson, 136 S. Ct. 1310, 1333-35 (2016) (Roberts, C.J., dissenting).

63. Patchak, 138 S. Ct. at $916-17$.

64. Id. at 916.

65. Id. at 917 .

66. See id. at $917-18$.

67. Id. at 918; see Commodity Futures Trading Comm'n v. Schor, 478 U.S. 833, 851 (1986) (explaining that the Court "review[s] Article III challenges . . . with an eye to the practical effect that the congressional action will have on the constitutionally assigned role of the federal judiciary").

68. Patchak, 138 S. Ct. at 918-19 (Roberts, C.J., dissenting).

69. Id at 918,919 . The Court has "previously found that nearly identical statutory language "says nothing about whether a federal court has subject-matter jurisdiction." Id. at 919 (quoting Reed Elsevier, Inc. v. Muchnick, 559 U.S. 154, 164 (2010)). Compare the statute in Reed Elsevier, which provides that "no civil action . . . shall be instituted," 559 U.S. at 164 , with $\S 2$ (b), which provides that "an action . . shall not be filed or maintained." Patchak, 138 S. Ct. at 919 (Roberts, C.J., dissenting).

70. Id. at 918-19 (first quoting Sebelius v. Auburn Reg'l Med. Ctr., 568 U.S. 145, 153 (2013); and then quoting Arbaugh v. Y \& H Corp., 546 U.S. 500, 515-16 (2006)). 
when it manipulates jurisdictional rules to decide the outcome of a particular pending case. Because the Legislature has no authority to direct entry of judgment for a party, it cannot achieve the same result by stripping jurisdiction over a particular proceeding." 71

Chief Justice Roberts also reasoned that $\S 2(\mathrm{~b})$, contrary to the plurality's interpretation, does not "change the law." 72 Changing the law instead requires "some measure of generality or preservation of an adjudicative role for the courts"-neither of which are present in $\S 2$ (b)..$^{73}$ Indeed, "[t]he Committees that recommended the legislation affirmed that the statute would make "no changes in existing [Indian] law." "74 If stripping jurisdiction over a single pending case changes the law, then "the plurality's rule 'provides no limiting principle' on Congress's ability" to encroach on the judiciary's constitutional role. ${ }^{75}$

Finally, Roberts rejected Justice Ginsburg's sovereign-immunity rationale, as well as Justice Breyer's concurrence. ${ }^{76}$

\section{B. Oil States Energy Services v. Greene's Energy Group}

The second Article III case of the October 2017 Term was Oil States Energy Services v. Greene's Energy Group. ${ }^{77}$ At issue in Oil States was the "inter partes review" procedure for reviewing patent validity. ${ }^{78}$ Inter partes review, established in 2012 by the Leahy-Smith America Invents Act, provides a non-exclusive, non-Article III alternative to judicial review of a patent decision. ${ }^{79}$ When an inventor seeks a patent from the United States Patent and Trademark Office (PTO), the PTO either "ap-

71. Id. at $919-20$.

72. Id. at $920-21$.

73. Id. at 920 .

74. Id. at 917 (alteration in original) (first quoting H.R. REP. No. 113-590, at 5 (2014); and then quoting S. ReP. No. 113-194, at 4 (2014)).

75. Id. at 920 (quoting N. Pipeline Constr. Co. v. Marathon Pipe Line Co., 458 U.S. 50, 73 (1982) (plurality opinion)). Chief Justice Roberts also engaged in colloquy with the plurality over the meaning of Ex parte McCardle. Compare Patchak, $138 \mathrm{~S}$. Ct. at 907 \& n. 4 (plurality opinion), with id. at 920-21 \& n.3 (Roberts, C.J., dissenting). Painting in broad strokes, Roberts suggested that Klein may have at least partially overruled McCardle. See $i d$. at 920-21 (Roberts, C.J., dissenting). In any event, the statute in McCardle was not so "brazen" as the Gun Lake Act, because it "did not foreclose all avenues for judicial review of McCardle's complaint." Id. at 921.

Section 2(b), on the other hand, has neither saving grace. It ends Patchak's suit for good. His federal case is dismissed, and he has no alternative means of review anywhere else. Section 2(b) thus reaches further than the typical jurisdictional repeal, which "takes away no substantive right but simply changes the tribunal that is to hear the case." Because $\S 2$ (b) singles out Patchak's suit, specifies how it must be resolved, and deprives him of any judicial forum for his claim, the decision to uphold that provision surpasses even McCardle as the highwater mark of legislative encroachment on Article III.

Id. (citations omitted) (quoting Landgraf v. USI Film Prods., 511 U.S. 244, 274 (1994)).

76. See id. at 921-22.

77. 138 S. Ct. 1365 (2018).

78. See 35 U.S.C. $\$ \$ 100-46$ (2012).

79. See Oil States, $138 \mathrm{~S}$. Ct. at 1371-72. 
proves or rejects the application." 80 Rejection of an application and validity of an approved patent are both subject to judicial review in Article III courts. ${ }^{81}$ Under inter partes review, any person other than the patent owner can file a petition with the PTO challenging the validity of a patent. ${ }^{82}$ After clearing initial procedural hurdles, the review proceeds before the Patent Trial and Appeal Board (Board), which "sits in threemember panels of administrative patent judges." ${ }^{33}$ During inter partes review

the petitioner and the patent owner are entitled to certain discovery; to file affidavits, declarations, and written memoranda; and to receive an oral hearing before the Board. The petitioner has the burden of proving unpatentability by a preponderance of the evidence. The owner can file a motion to amend the patent by voluntarily canceling a claim or by "propos[ing] a reasonable number of substitute claims." 84

Ultimately, the Board issues a written decision on the patent's validity. ${ }^{85}$ Parties can then seek judicial review of a Board decision in the Federal Circuit. 86

Oil States Energy Services, LLC, an oilfield services company, obtained a patent "relating to an apparatus and method for protecting wellhead equipment used in hydraulic fracturing." 87 About a decade later, it sued Greene's Energy Group, LLC for patent infringement. ${ }^{88}$ Greene's Energy challenged the patent's validity in federal district court and also sought inter partes review with the Board. ${ }^{89}$ The district court and the Board reached opposite conclusions, with the Board concluding that Oil States's original claims were unpatentable. ${ }^{90}$ Oil States appealed to the Federal Circuit, where it argued that inter partes review violates Article

\footnotetext{
80. Id. at 1370 .

81. Id. at 1372 .

82. Id. at 1371 .

83. $I d$. "specification").

85. Oil States, 138 S. Ct. at 1371.

86. Id. at 1372 .

87. Id.

88. Id.

89. Id.

90. Id.
}

84. Id. (alteration in original) (citations omitted) (quoting 35 U.S.C. $\S 316(a)(5)$, (8), $(10),(d)(1)(B),(e)(2012))$. Several differences exist between inter partes review and district court review of patent validity, including burden of proof, compare, e.g., Novartis AG v. Noven Pharm. Inc., 853 F.3d 1289, 1294 (Fed. Cir. 2017) (stating that a patent challenger must prove invalidity before the Board by a preponderance of the evidence), with Sciele Pharma Inc. v. Lupin Ltd., 684 F.3d 1253, 1260 (Fed. Cir. 2012) (stating that, in district court, a patent challenger must prove invalidity by clear and convincing evidence), and claim construction standards, compare, e.g., In re Cuozzo Speed Techs., 793 F.3d 1268, 1277 (Fed. Cir. 2015) (stating that the "PTO[] giv[es] claims their broadest reasonable construction"), with Phillips v. AWH Corp., 415 F.3d 1303, 1314-15 (Fed. Cir. 2005) (stating that district courts construe claims based on "the claims themselves" and the 
III. 91

In Oil States, like in Patchak, Justice Thomas wrote the lead opinion, this time garnering a majority along with Justices Kennedy, Ginsburg, Breyer, Alito, Sotomayor, and Kagan. Breyer also filed a concurring opinion, in which Ginsburg and Sotomayor joined. ${ }^{92}$ Justice Gorsuch dissented, joined by Chief Justice Roberts. ${ }^{93}$ The majority evaluated the Article III challenge under the framework of the "public-rights" doctrine, which gives Congress "significant latitude to assign adjudication of public rights to entities other than Article III courts." 94 At its most basic, the public-rights doctrine provides that adjudication of private rights must be performed by the judiciary, whereas adjudication of matters "arising between the government and others" are "susceptible" to "judicial determination" but do not "require" it. ${ }^{95}$ Congress can create non-Article III tribunals to adjudicate public rights.

The majority held that "[i]nter partes review falls squarely within the public-rights doctrine." 96 The "decision to grant a patent"-a form of public franchise-indisputably involves public rights. ${ }^{97}$ And "[i]nter partes review," continued the majority, "is simply a reconsideration of that grant" (in no small part because the Board applies the same standards the PTO does when it first decides whether to issue the patent). ${ }^{98}$ Congress's decision to reserve an adjudicatory role for the Board, therefore, does not violate Article III. ${ }^{99}$

The majority rejected Oil States's appeal to case law recognizing patents as private property. ${ }^{100}$ Although rights granted by a patent may indeed be private, those rights are granted "[s]ubject to the provisions of" the Patent Act, which include inter partes review. ${ }^{101}$ What the government grants, it may limit.

Along similar lines, the majority also supported its position with evidence of historical practice. ${ }^{102}$ According to the majority, during the eighteenth century in the run-up to the Founding Era, patent validity was decided both by English courts of law and alternatively by the English Privy Council via a procedure not unlike inter partes review. ${ }^{103}$ This evi-

91. Id. Oil States also challenged inter partes review as violating the Seventh Amendment to the U.S. Constitution. Id. The Court rejected that challenge as well. Id. at 1379.

92. Id. at 1379-80 (Breyer, J., concurring).

93. Id. at 1380-86 (Gorsuch, J., dissenting).

94. Id. at 1373 (majority opinion).

95. Id. (quoting Ex parte Bakelite Corp., 279 U.S. 438, 451 (1929)).

96. Id.

97. Id. (emphasis added).

98. Id.

99. Id. at 1373,1375 . Indeed, as the majority pointed out, inter partes review decides the rights of a party only vis-à-vis the government; it "does not make any binding determination regarding 'the liability of [Greene's Energy] to [Oil States] under the law as defined." "Id. at 1378 (quoting Crowell v. Benson, 285 U.S. 22, 51 (1932)).

100. Id. at $1375-76$.

101. Id. at 1375 (quoting 35 U.S.C. $\$ 261$ (2012)).

102. Id. at 1376-77. In doing so, it directly rejected the dissent's interpretation of the same evidence. Compare id., with id. at 1381-84 (Gorsuch, J., dissenting).

103. Id. at 1376-77 (majority opinion). 
dence led the majority to "disagree with the dissent's assumption that, because courts have traditionally adjudicated patent validity in this country, courts must forever continue to do so." 104 Concluding by emphasizing the narrowness of its decision, the Court held that inter partes review is constitutional under Article III. ${ }^{105}$

Justice Breyer authored a short concurring opinion, joined by Justices Ginsburg and Sotomayor, suggesting that in some instances private rights may be adjudicated outside of Article III tribunals, too. ${ }^{106}$

Justice Gorsuch penned a dissent, in which Chief Justice Roberts joined. ${ }^{107}$ Rebuking the majority opinion as an "invit[ation] . . . to retreat from the promise of judicial independence," Gorsuch challenged the essential premise that inter partes review involves adjudication of public rights. ${ }^{108}$

Original public meaning, as illustrated by English and American legal practice during the Founding Era, laid the foundation for Gorsuch's analysis.

As originally understood, the judicial power extended to "suit[s] at the common law, or in equity, or admiralty." . . . "[W]hen a suit is made of the stuff of the traditional actions at common law tried by the courts at Westminster in $1789 \ldots$ and is brought within the bounds of federal jurisdiction, the responsibility for deciding that suit rests with" Article III judges . . . ${ }^{109}$

Despite invoking the same historical-practice evidence Justice Thomas did, Justice Gorsuch interpreted it differently and reached a different conclusion. "[A]t the time of the founding," Gorsuch declared, "only courts could hear patent challenges in England . . .."110 Although the Privy Council may have theoretically enjoyed the power to invalidate patents, it had not actually exercised that power since $1746 .{ }^{111}$ This fact alone decided the case for Gorsuch.

What is more, Gorsuch read the historical evidence as supporting a shift in thinking about patent rights over time. Originally conceived of as "feudal favors," patents gradually became thought of as private property

104. Id. at 1378.

105. Id. at 1379 . The Court addressed only "the constitutionality of inter partes review" with respect to Article III and not "whether other patent matters, such as infringement actions, can be heard in a non-Article III forum." Id. Oil States also argued that "inter partes review violates Article III because it shares 'every salient characteristic associated with the exercise of the judicial power.' Id. at 1378 (quoting Brief for Petitioner at 20, Oil States, 138 S. Ct. 1365 (No. 16-712), 2017 WL 3713059, at *20). The Court rejected this argument, refusing to adopt a "looks like" test: "[t]he fact that an agency uses court-like procedures does not necessarily mean it is exercising the judicial power." Id.

106. Id. at 1379-80 (Breyer, J., concurring).

107. Id. at 1380 (Gorsuch, J., dissenting).

108. Id.

109. Id. at 1381 (alteration in original) (citations omitted) (first quoting Murray's Lessee v. Hoboken Land \& Improvement Co., 59 U.S. (18 How.) 272, 284 (1856); and then quoting Stern v. Marshall, 564 U.S. 462, 484 (2011)).

110. Id. (emphasis added).

111. Id. at 1382 . 
rights thanks to a "change in perception[] from viewing a patent as a contract between the crown and the patentee to viewing it as a "social contract' between the patentee and society."112 Indeed, "by the time of the founding the law treated patents protected by the Patent Clause quite differently from ordinary public franchises."113

Early American courts, Gorsuch explained, placed a greater emphasis on the private-property nature of patents than did their English counterparts. ${ }^{114}$ Whereas English judges treated the patent grant more as a matter of favor, American judges - including Chief Justice John Marshallconceived of a patent as "inchoate property" to which the inventor is entitled as of right. ${ }^{115}$ And at least until recent changes to the Patent Act, patent-validity disputes were always litigated in Article III courts. ${ }^{116}$

In a final appeal to pure logic, Gorsuch suggested that the majority had analyzed a case about the revocation of a patent through a framework designed for the issuance of one. ${ }^{117}$ "Just because you give a gift doesn't mean you forever enjoy the right to reclaim it."118 All told, Gorsuch would have held that inter partes review violates Article III and the separation of powers.

\section{GiLl V. Whitford}

The most highly publicized of the three Article III cases of the October 2017 Term was Gill v. Whitford. ${ }^{119}$ In Gill, Wisconsin Democratic voters claimed that state legislative districts had been unconstitutionally gerrymandered to ensure Republican advantage. ${ }^{120}$ Every ten years, the Wisconsin Legislature redraws the state's legislative districts. ${ }^{121}$ Following the 2010 census, Wisconsin enacted an apportionment map known as Act 43. The Republican Party fared well under the map: "In 2012, Republicans won 60 [of 99] Assembly seats with $48.6 \%$ of the two-party statewide vote for Assembly candidates. In 2014, Republicans won 63 Assembly

112. Id. (quoting Edward C. Waltersheid, The Early Evolution of the United States Patent Law: Antecedents (Part 3), 77 J. Pat. \& Trademark Off. Soc'y 771, 793 (1995)).

113. Id. at 1385 .

114. Id. at $1383-84$.

115. Id. at 1384 (quoting Evans v. Jordan, 8 F. Cas. 872, 873 (C.C.D. Va. 1813) (No. 4,564), aff'd, 13 U.S. (9 Cranch) 199 (1815)).

116. Id. Justice Gorsuch also relied on an 1898 case ostensibly holding that the executive branch could not reconsider a patent grant. Id. at 1384-85 (quoting McCormick Harvesting Mach. Co. v. Aultman, 169 U.S. 606, 608-09 (1898)). The majority distinguished McCormick on the grounds that it was interpreting the specific patent statutes in effect at the time (Patent Act of 1870), not necessarily the Constitution. Id. at 1376 n.3 (majority opinion). But even the McCormick Court, as Justice Gorsuch pointed out, used constitutional language and based its decision in part on separation of powers principles. Id. at 1384-85 (Gorsuch, J., dissenting).

117. Id. at 1385 .

118. Id.

119. 138 S. Ct. 1916 (2018). The author and other attorneys at Husch Blackwell LLP authored an amicus curiae brief in Gill.

120. Id. at 1922-23.

121. Id. at 1923 (citing WIs. Const. art. IV, § 3). 
seats with $52 \%$ of the statewide vote." 122

In response to the Republicans' success, twelve Wisconsin Democratic voters from legislative districts around the state brought an action in federal district court challenging the constitutionality of Act 43 under the Equal Protection Clause and the First Amendment. ${ }^{123}$ "Four of the plaintiffs ... alleged that they lived in State Assembly districts where Democrats have been cracked or packed." 124 All of the plaintiffs also alleged that, regardless of cracking or packing in their specific districts, they had suffered harm because "Democrats statewide 'do not have the same opportunity provided to Republicans to elect representatives of their choice to the Assembly." "125

The case proceeded to a merits trial, at which the plaintiffs presented two principal types of evidence. ${ }^{126}$ First was fact-witness testimony, including that of the lead plaintiff, Whitford. ${ }^{127}$ Second was expert testimony, including a body of social-science evidence measuring Act 43's effect on Wisconsin elections. ${ }^{128}$ The defendants presented expert testimony, too, countering that the plaintiffs' evidence did not substantiate their assertions of "durable partisan advantage" and that Wisconsin's "political geography"129 naturally favors Republicans. ${ }^{130}$ The district court concluded, $2-1,131$ that Act 43 was an unconstitutional partisan gerrymander in violation of the First and Fourteenth Amendments to the U.S. Constitution. ${ }^{132}$ To get there, the district court first concluded that the plaintiffs all had established Article III standing. ${ }^{133}$

On appeal, the U.S. Supreme Court vacated and remanded. ${ }^{134}$ Chief

122. Id.

123. Id. at $1923-24$.

124. Id. at 1924. "Cracking means dividing a party's supporters among multiple districts so that they fall short of a majority in each one. Packing means concentrating one party's backers in a few districts that they win by overwhelming margins." Id. (quoting Joint Appendix Volume I: Complaint, at 29 II 5, Gill, 138 S. Ct. 1916 (No. 16-1161), 2017 WL 4326639 , at $* 29$ [hereinafter Complaint]).

125. Id. (quoting Complaint, supra note 124, at 33 If 16).

126. Id. at 1924-25.

127. Id. Whitford conceded that Act 43 had not "affected [his] ability to vote for and elect a Democrat in [his] district." Id. at 1925 (alterations in original) (quoting Transcript of Record at 37, Whitford v. Nichol, 151 F. Supp. 3d 918, 924 (W.D. Wis. 2015) (No. 147)). Still, he testified that he suffered harm "relate[d] to [his] ability to engage in campaign activity to achieve a majority in the Assembly and the Senate." Id. (alterations in original) (quoting Transcript of Record at 37, Whitford, 151 F. Supp. 3d 918 (No. 147)).

128. Id. at 1925.

129. "Political geography" refers to how efficiently voters of each party are distributed across geographical space. Democratic voters in Wisconsin, for instance, "tend to be clustered in large cities," which has a certain self-limiting effect on how districts can be drawn. See id.

130. Id.

131. In federal district court, three-judge panels hear challenges to the constitutionality of statewide legislative apportionment. 28 U.S.C. § 2284(a) (2012).

132. Gill, 138 S. Ct. at 1925-26; see Whitford v. Gill, 218 F. Supp. 3d 837, 910 (W.D. Wis. 2016), vacated and remanded, 138 S. Ct. 1916 (2018).

133. Gill, 138 S. Ct. at 1926.

134. Decisions of three-judge district court panels are appealable directly to the U.S. Supreme Court. 28 U.S.C. $\S 1253$ (2012). 
Justice Roberts authored the opinion of the Court, in which seven Justices joined in full and two joined in every respect except for a short section about remand. ${ }^{135}$ Writing for a unanimous Court, Roberts began by cataloguing in great detail its past partisan-gerrymandering case law. This exercise exposed profound uncertainty as to whether such claims were justiciable and, if so, what standards applied. ${ }^{136}$ After tracing the Court's "considerable efforts" in the prior cases, "two threshold questions remain[ed]" in Gill: "what is necessary to show standing in a case of this sort, and whether those claims are justiciable." 137

The Court decided the standing question against the plaintiffs, leaving no need to address justiciability. ${ }^{138}$ Outlining the general, well-known Article III standing requirements, the Court explained that plaintiffs seeking to invoke federal judicial power must plead and prove that they "(1) suffered an injury in fact, (2) that is fairly traceable to the challenged conduct of the defendant, and (3) that is likely to be redressed by a favorable judicial decision."139 An "injury in fact" must be "concrete and particularized," which "affect[s] the plaintiff in a personal and individual way." 140 Requiring this showing ensures that federal courts do not act as "forum[s] for generalized grievances." 141

Applying these general standing principles to a plaintiff alleging an Equal-Protection-violating apportionment map was the Court's next step. ${ }^{142}$ In past cases, the Court had explained that voters can establish standing only if they "allege facts showing disadvantage to themselves as individuals." 143 The Gill plaintiffs challenged Act 43, which apportioned Wisconsin's single-member legislative districts; "[a]n individual voter in Wisconsin is placed in a single district ... [and] votes for a single representative."144 "The boundaries of the district, and the composition of its voters," the Court reasoned, "determine whether and to what extent a particular voter is packed or cracked." 145 To that end, the Court held that to show "disadvantage to themselves as individuals" and thereby estab-

135. See Gill, 138 S. Ct. at 1941 (Thomas, J., concurring).

136. Id. at 1926-29 (majority opinion) (first citing Gaffney v. Cummings, 412 U.S. 735 (1973) (rejecting "political gerrymander" claim); then citing Davis v. Bandemer, 478 U.S. 109 (1986) (agreeing that claim of unconstitutional partisan gerrymandering was justiciable but failing to settle on a single standard); then citing Vieth v. Jubelirer, 541 U.S. 267 (2004) (regarding the justiciability of and standards applicable to partisan gerrymandering claims); and then citing League of United Latin Am. Citizens v. Perry, 548 U.S. 399 (2006) (same)).

137. Gill, 138 S. Ct. at 1929.

138. Id.

139. Id. (quoting Spokeo, Inc. v. Robins, 136 S. Ct. 1540, 1547 (2016)).

140. Id. (alteration in original) (quoting Lujan v. Defs. of Wildlife, 504 U.S. 555, 560 \& n.1 (1992)).

141. Id. (quoting Lance v. Coffman, 549 U.S. 437, 439, 441 (2007) (per curiam)).

142. At the Supreme Court, the plaintiffs pursued, nearly exclusively, a vote-dilution theory under the Equal Protection Clause. Earlier in the case and in the pleadings, they had also alleged a First Amendment freedom-of-association violation. Id. at 1931. See also $i d$. at 1937-40 (Kagan, J., concurring).

143. Id. at 1929 (majority opinion) (quoting Baker v. Carr, 369 U.S. 186, 206 (1962)).

144. Id. at 1930.

145. Id. 
lish Article III standing, the plaintiffs had to plead and prove districtspecific injury. ${ }^{146}$

Under this standard, the Gill plaintiffs failed to establish Article III standing. At trial, they trumpeted "the statewide harm to their interest "in their collective representation in the legislature" "but neglected to show district-specific injury to themselves as individual voters. ${ }^{147}$ This, the Court held, did not constitute a concrete and particularized injury in fact: "[a] citizen's interest in the overall composition of the legislature is embodied in his right to vote for his representative," which is an interest and a right "common to all members of the public." 148

Although four of the plaintiffs had initially pleaded district-specific cracking-or-packing injuries, they chose not to prosecute their case through trial along those lines, instead joining the other plaintiffs in pursuing a theory of statewide injury. ${ }^{149}$ In short, no plaintiff actually proved that he or she "live[d] in a cracked or packed district." 150 The fact-witness testimony did not even purport to show as much, and the expert testimony and social-science evidence all related to the statewide fortunes of political parties, not to the effect of Act 43 on any particular voter. ${ }^{151}$ Gill thus amounted to "a case about group political interests, not individual legal rights." 152

When plaintiffs fail to establish Article III standing, the Court "usually" dismisses the case. ${ }^{153}$ Nonetheless, seven Justices acknowledged the "unsettled . . . contours" of partisan-gerrymandering claims, as well as Gill's unique circumstances. ${ }^{154}$ To that end, the Court agreed to remand the case instead of dismissing it, giving the plaintiffs another chance to show concrete and particularized injury. ${ }^{155}$

Justice Kagan filed a concurring opinion, in which Justices Ginsburg, Breyer, and Sotomayor joined. ${ }^{156}$ The concurrence, while agreeing in full with the majority's analysis of the law and record to that point, offered some "observations" about what evidence could be used to show standing on remand. ${ }^{157}$ In addition, Kagan commented on how the plaintiffs, should they pursue their First Amendment theory in a more meaningful

146. Id. (quoting Baker, 369 U.S. at 206).

147. Id. at 1931 (quoting Brief for Appellees at 31, Gill, 138 S. Ct. 1916 (No. 16-1161), 2017 WL 3726003, at *31). The Gill plaintiffs ultimately conflated injury and remedy when arguing that prior precedent permitted them to proceed on a statewide injury theory. Id. at 1930. Under a proper district-specific injury theory, though, a conceivable remedy could be the statewide alteration of district lines. Relatedly, the Court requires plaintiffs in analogous racial-gerrymandering cases to prove vote dilution in a specific district. Id.

148. Id. at 1931 (quoting Ex parte Levitt, 302 U.S. 633, 634 (1937) (per curiam)).

149. Id. at 1931-32. A plaintiff must both plead and prove facts necessary to establish standing. Lujan v. Defs. of Wildlife, 504 U.S. 555, 561 (1992).

150. Gill, 138 S. Ct. at 1932.

151. See id. at 1932-33.

152. Id. at 1933 .

153. Id.

154. Id. at 1934

155. Id.

156. Id. at 1934-41 (Kagan, J., concurring).

157. Id. at 1934; see id. at 1934-37, 1941. 
way, could satisfy Article III's standing requirement based on statewide injury. ${ }^{158}$

Finally, Justice Thomas, joined by Justice Gorsuch, concurred in part and concurred in the judgment. ${ }^{159}$ The two joined in the majority opinion except for the last section remanding the case to give the plaintiffs another chance to establish Article III standing. ${ }^{160}$ Rather, they would have followed the Court's "ordinary practice" when plaintiffs fail to show standing and "remand[ed] the case with instructions to dismiss for lack of jurisdiction." 161

\section{THE CASES: DISCOVERING JUDICIAL RESTRAINT AS A UNIFYING PRINCIPLE}

Each of the three Article III cases the Supreme Court decided during its October 2017 Term was, of course, unique. But this Part focuses on the cases' similarities: it examines holdings and outcomes and sets aside, for the moment, dispensable concurrences and dissents. For this Part, then, the relevant opinions include the Patchak plurality, Justice Ginsburg's necessary concurrence in the judgment in Patchak, the Oil States majority, and the Gill majority. Using these opinions, this Part aims to discover a unifying principle that explains the holdings and outcomes in the three cases.

Patchak, Oil States, and Gill all share at least one obvious similarity: they involved questions arising under Article III. Relatedly, and perhaps as a necessary corollary, they each implicated the separation of powers. Asking the most abstract separation of powers questions, Patchak required the Court to interpret the Klein principle and delineate a boundary between legislative and judicial power with respect to pending lawsuits. In Oil States, a case also laden with separation of powers issues, the Court opined on the contours of the public-rights doctrine. And in Gill, the Court deployed yet another Article III doctrine "built on separation of powers principles"162_-standing.

Each of the three cases posed a specific and distinct question about Article III power and, at least implicitly, the separation of powers. In Patchak, the petitioner (Patchak) asked the Court to answer the following question: "Does a statute directing the federal courts to "promptly dismiss' a pending lawsuit following substantive determinations by the courts (including this Court's determination that the 'suit may pro-

158. Id. at $1937-40$.

159. See id. at 1941 (Thomas, J., concurring).

160. Id.

161. Id.

162. Susan B. Anthony List v. Driehaus, 573 U.S. 149, 157 (2014) (quoting Clapper v. Amnesty Int'l USA, 568 U.S. 398, 408 (2013)); accord Raines v. Byrd, 521 U.S. 811, 820 (1997); Allen v. Wright, 468 U.S. 737, 752 (1984) (plurality opinion); see, e.g., F. Andrew Hessick, The Separation of Powers Theory of Standing, 95 N.C. L. REv. 673 (2017); Antonin Scalia, The Doctrine of Standing as an Essential Element of the Separation of Powers, 17 Suffolk U. L. Rev. 881 (1983); see also infra notes 225-249 and accompanying text. 
ceed') - without amending underlying substantive or procedural lawsviolate the Constitution's separation of powers principles?"163 As the plurality simplified it, the question before the Court was "whether $\S 2(\mathrm{~b})$ [of the Gun Lake Act] violates Article III of the Constitution."164 Distilled to its most basic level, the question presented offered the Court two dispositive options: it could either hold that the Gun Lake Act does violate Article III and the separation of powers, or that it does not. ${ }^{165}$

Next, in Oil States, the petitioner (Oil States) asked the Court to answer the following question: "Whether inter partes review-an adversarial process used by the Patent and Trademark Office (PTO) to analyze the validity of existing patents-violates the Constitution by extinguishing private property rights through a non-Article III forum without a jury." 166 The Court, simplifying as it did in Patchak, recognized its charge as addressing "whether inter partes review violates Article III . . . ."167 The Court thus had two options: it could hold that inter partes review does violate Article III or that it does not.

Finally, in Gill, the appellants (Gill et al.) asked the Court to answer the following question, among others: "Did the district court lack jurisdiction over this case because Plaintiffs have no [Article III] standing to bring their statewide partisan-gerrymandering claims?"168 Thus, the Court had two options: it could hold that the plaintiffs did have standing, such that a federal court could exercise its Article III power, or that they did not.

163. Brief for Petitioner at i, Patchak v. Zinke, 138 S. Ct. 897 (2018) (No. 16-498), 2017 WL 3033945, at $*$ i. The tribal respondents framed the question presented similarly: "Does a statute that bars all federal actions (pending and future) concerning a parcel of land taken into trust by the federal government violate the Constitution's separation of powers principles?" Brief for Respondent Match-E-Be-Nash-She-Wish Band of Pottawatomi Indians at i, Patchak, 138 S. Ct. 897 (No. 16-498), 2017 WL 4022034, at*i. So too did the federal respondents: "Whether Congress may prohibit actions related to this particular parcel of land from being filed or maintained in the federal courts, and order that pending cases meeting that standard be dismissed, without intruding on the role of the judiciary under constitutional separation of powers principles." Brief for the Federal Respondents at I, Patchak, 138 S. Ct. 897 (No. 16-498), 2017 WL 4023123, at *I.

164. Patchak, 138 S. Ct. at 904 (plurality opinion).

165. Justices Ginsburg and Sotomayor, of course, found a third way: they would have sidestepped the Article III question and decided the case on sovereign-immunity grounds. See id. at 912 (Ginsburg, J., concurring).

166. Brief for Petitioner, supra note 105, at i. Respondent Greene's Energy Group, LLC, framed the question presented exactly the same. Brief in Opposition at i, Oil States Energy Servs., LLC v. Greene's Energy Grp., LLC, 138 S. Ct. 1365 (2018) (No. 16-712), 2017 WL 411377, at *i. The federal respondent posed a slightly simpler version: "Whether inter partes review comports with Article III and the Seventh Amendment." Brief for the Federal Respondent in Opposition at I, Oil States, 138 S. Ct. 1365 (No. 16-712), 2017 WL 1632445 , at $* \mathrm{I}$.

167. Oil States Energy Servs., LLC v. Greene's Energy Grp., LLC, 138 S. Ct. 1365, 1370 (2018).

168. Brief for Appellants at i, Gill v. Whitford, 138 S. Ct. 1916 (2018) (No. 16-1161), 2017 WL 3485551, at*i. Appellees framed the question presented similarly: "Whether the district court correctly held that Appellees have standing to challenge in its entirety the district plan for Wisconsin's State Assembly as an unconstitutional partisan gerrymander?" Brief for Appellees, supra note 147, at i. 
So, in both Patchak and Oil States, the Court needed to decide whether a particular statute violated Article III (and the separation of powers). If the Court in either case were to hold that the statute violated Article III, that holding could fairly be characterized as an assertion of - or, at least, a self-defense of-the judiciary's own Article III power. On the other hand, if the Court were to hold that the statute was constitutionally permissible and not in violation of Article III, that holding could fairly be characterized as the converse of an assertion of self-defense of Article III power. In essence, the Court's holding in both cases would come down either in favor of its own Article III power or against its own Article III power.

Gill presented the Court with a similar situation. The Court needed to decide whether the plaintiffs had Article III standing. If the Court were to hold that the plaintiffs did have standing, thereby enabling the exercise of Article III power, then that holding could fairly be characterized as an assertion of the judiciary's own Article III power. On the other hand, if the Court were to hold that the plaintiffs did not have standing (or that they had not established standing), thereby precluding the exercise of Article III power, then that holding could fairly be characterized as the converse of an assertion of Article III power. Just like in Patchak and Oil States, then, the Court's holding in Gill would come down either in favor of its own Article III power or against its own Article III power. ${ }^{169}$

In all three cases, the Court held against its own Article III power. In other words, the holdings of all three cases represented the converse of an assertion (or self-defense) of the Court's own Article III power. In Patchak, with help from Justice Ginsburg's non-Article III concurrence in the judgment, the Court held that the Gun Lake Act does not violate Article III and the separation of powers. Patchak had argued that Congress encroached too far on the judiciary's power, but the Court permitted Congress's action to stand. In Oil States, the Court held that inter partes review does not violate Article III. Oil States had argued that Congress gave an executive agency a task exclusively within the province of the judiciary, but the Court permitted Congress's action to stand. And in Gill, the Court held that the plaintiffs had failed to establish Article III standing. The plaintiffs had argued that they had suffered an injury concrete and particularized enough to allow the judiciary to exercise its Article III power, but the Court disagreed. In sum, in each case the litigants presented the Court with a clear option to assert or fortify its own Article III power and to defend the judiciary's scope of authority against en-

169. This paragraph should not be read as dismissing real differences between Gill and the other two cases. In Gill, the Court explained that Article III standing doctrine reflects both the affirmative role of courts and a reflexive limit on that role. Standing ensures that federal courts exercise only truly judicial power and do not become "forum[s] for generalized grievances." Gill, 138 S. Ct. at 1929 (quoting Lance v. Coffman, 549 U.S. 437, 439 (2007) (per curiam)). The polar comparison between an assertion (or self-defense) of Article III power, on the one hand, and the converse, on the other hand, may in fact be less forceful and apposite in standing cases (like Gill) than it is in other Article III cases (like Patchak and Oil States). See also infra notes 225-249 and accompanying text. 
croachment. In all three cases, the Court declined to do so, instead holding the opposite.

The above exposition discloses a central unifying principle-a common judicial philosophy, perhaps-that underlies and accounts for the holdings in all three cases: judicial restraint. The term "judicial restraint," as Judge Posner has said, is a "chameleon." 170 According to Posner, the term has three potential meanings: the first, that "judges apply law, they don't make it," which Posner calls "the law made me do it" restraint; the second, that "judges defer to a very great extent to decisions by other officials," which Posner calls "modesty" or "institutional competence;" and the third, that "judges are highly reluctant to declare legislative or executive action unconstitutional," which Posner calls "constitutional restraint." 171 The third meaning of "judicial restraint" (constitutional restraint) relates to the second (modesty), but the two are "differently motivated." 172 Whereas modesty alone "is motivated by notions of comparative institutional competence," constitutional restraint is motivated more so "by respect for the elected branches of government . ..."173 As legal commentator Damon Root has written, "judicial restraint"- -specifically, constitutional restraint in Posnerian parlance-is "the idea that judges should defer to the will of the majority and refrain from striking down most democratically enacted laws, even the really dumb ones." 174 At its zenith, constitutional restraint opposes the very idea of judicial review, ${ }^{175}$ insisting that "[f]or protection against abuses by legislatures the people must resort to the polls, not to the courts." 176 Preeminent figures

170. Richard A. Posner, The Rise and Fall of Judicial Self-Restraint, 100 CALIF. L. Rev. 519,520 (2012). For more on the concept of "judicial restraint," see generally RoBERT H. Bork, The Tempting of America (1990); Damon Root, Overruled: The Long War for Control of the U.S. Supreme Court (2014); Lee Epstein \& William M. Landes, Was There Ever Such a Thing as Judicial Self-Restraint?, 100 Calif. L. Rev. 557 (2012); Aziz Z. Huq, When Was Judicial Self-Restraint?, 100 CALIF. L. Rev. 579 (2012); Pamela S. Karlan, The Transformation of Judicial Self-Restraint, 100 CALIF. L. REv. 607 (2012); Larry D. Kramer, Judicial Supremacy and the End of Judicial Restraint, 100 Calif. L. Rev. 621 (2012); Roger Pilon, Foreword, The Roberts Court Emerges: Restrained or Active?, 2007 Cato Sup. Cт. Rev. vii, xi (2007); Jeffrey Rosen, Originalism, Precedent, and Judicial Restraint, 34 HARv. J.L. \& PUB. POL'y 129 (2011).

171. Posner, supra note 170, at 520-21. Other definitions and explanations of "judicial restraint" exist, too. One form of judicial restraint, often termed judicial minimalism, counsels courts to decide cases on the narrowest grounds possible, as well as to generally avoid deciding constitutional questions. See, e.g., Tara Smith, Reckless Caution: The Perils of Judicial Minimalism, 5 N.Y.U. J.L. \& LiberTy 347, 356 (2010). Judicial minimalism differs from the Posnerian conceptions and does not necessarily implicate separation of powers concerns. See Posner, supra note 170, at 521 (arguing that judicial minimalism is not a form of judicial restraint). Then-Judge Roberts once wrote that "the cardinal principle of judicial restraint" is that "if it is not necessary to decide more, it is necessary not to decide more." PDK Labs., Inc. v. DEA, 362 F.3d 786, 799 (D.C. Cir. 2004) (Roberts, J., concurring); see Morse v. Frederick, 551 U.S. 393, 431 (2007) (Breyer, J., concurring) (quoting PDK Labs, 362 F.3d at 799).

172. Posner, supra note 170 , at 521.

173. Id.

174. Root, supra note 170 , at 1.

175. See Posner, supra note 170 , at 521.

176. Munn v. Illinois, 94 U.S. 113, 134 (1877). 
of the Supreme Court have championed the constitutional-restraint brand of judicial restraint over the past century and more, ${ }^{177}$ whatever its merits. ${ }^{178}$

Judge Posner's explication of "judicial restraint" informs my use of that term here. More specifically, I use the term "judicial restraint" only in the context of Article III issues to describe how the Supreme Court, when given the choice between exercising, asserting, fortifying, or self-defending the judiciary's own Article III power on the one hand and not doing so (or doing the opposite) on the other hand, chooses to do the latter. To that end, I borrow Judge Posner's "constitutional restraint" conception of judicial restraint insofar as the Court's decisions to uphold the Gun Lake Act or inter partes review, or to determine that the Gill plaintiffs lacked standing, are motivated by respect for the elected branches.

Indeed, the brand of judicial restraint exemplified by the holdings in Patchak, Oil States, and Gill cannot be fully explained by modesty, as expressed through deference to other branches' perceived advantages in expertise. Consider, for example, a challenge to a law based on non-Article III grounds, such as the Equal Protection Clause. The Court may uphold the law, basing its decision in part on deference to Congress as the better, or even the exclusive, policymaking branch of government. In this regard, Chevron deference also comes to mind. ${ }^{179}$ By contrast, Patchak, Oil States, and Gill all involved questions of the judiciary's own power under Article III.

Exercising judicial restraint when the judiciary's own Article III power is at issue is different in kind from exercising judicial restraint when the judiciary's own Article III power is not (substantially) at issue. The latter exercise, in Posnerian terms, is most often informed by concerns of modesty or "institutional competence," while the former smacks of true constitutional restraint. Reading Patchak and Oil States, one is hard-pressed to find passages alluding to Congress's superior ability to make policy; rather, those opinions involve either the application of a doctrine (the public-rights doctrine in Oil States) or an interpretation of a line of precedent (the Klein principle in Patchak) that functionally implements consti-

177. See, e.g., Nat'l Fed'n of Indep. Bus. v. Sebelius, 567 U.S. 519, 538 (2012) ("It is not our job to protect the people from the consequences of their political choices."); W. Va. State Bd. of Educ. v. Barnette, 319 U.S. 624, 666 (1943) (Frankfurter, J., dissenting) ("As appeal from legislation to adjudication becomes more frequent, and its consequences more far-reaching, judicial self-restraint becomes more and not less important, lest we unwarrantably enter social and political domains wholly outside our concern."); Blodgett v. Holden, 275 U.S. 142, 148 (1927) (Holmes, J., concurring) (“[B]etween two possible interpretations of a statute, by one of which it would be unconstitutional and by the other valid, our plain duty is to adopt that which will save the Act."); see also Damon Root, How Judicial Restraint Shaped John Roberts' ObamaCare Decision, ReAson (June 29, 2012, 9:30 AM), https://reason.com/2012/06/29/how-judicial-restraint-shaped-john-rober.

178. This Article takes no position, one way or another, on the wisdom of judicial restraint, no matter how defined. I intend for this Article's commentary on judicial restraint to be wholly descriptive and not prescriptive or normative in any way.

179. See Chevron, U.S.A., Inc. v. Nat. Res. Def. Council, Inc., 467 U.S. 837, 843-44 (1984). 
tutional restraint. And then there is Gill, which decided against the assertion of Article III power on standing grounds. Standing, developed in the first half of the previous century to excuse federal courts from exercising Article III power, may indeed be the apogee of judicial restraint in its constitutional-restraint form. ${ }^{180}$

That judicial restraint can coherently explain the Court's 2017 Article III jurisprudence should not go underappreciated. The three cases each dealt with a different aspect of Article III power: Patchak with abstract separation of powers principles and the Klein principle, Oil States with the public-rights doctrine, and Gill with standing. Despite these differences, a majority of the Court in each case was able to coalesce around at least one common polestar-judicial restraint. Though a sample size of three might sound small, the breadth of doctrine covered and the comparatively low volume of total Article III cases over time suggest that those three cases are significant for analyzing the Court's past, present, and future tendencies. Indeed, they may provide some guidance for predicting the Court's Article III jurisprudence going forward. It is true that Justice Brett Kavanaugh now sits in Justice Kennedy's stead and that his views on Article III power have not yet been tested at the High Court. Even so, there is no reason to believe that judicial restraint will not continue to at least implicitly guide several members of the Court in future Article III cases. In many of those cases, judicial restraint-that is, favoring a restrained approach to asserting Article III power and erring on the side of not asserting it—will likely carry the day. ${ }^{181}$

\section{THE JUSTICES: MAKING SENSE OF INDIVIDUAL NUANCES}

The preceding Part showed how the holdings in Patchak, Oil States, and Gill can be conceptually organized around a unifying principle of judicial restraint. Those three cases, however, were not decided by a hive mind; they were decided by nine individual human beings. As a result, each case produced at least three opinions, with the Justices forming myriad different alliances. Rather than stopping at the case level of analysis, this Part drills down further and seeks to make sense of each individual Justice across the three cases, including: (1) how each Justice's opinions across the cases relate to or differ from one another; (2) how those opinions compare to and contrast with the opinions of other Justices; (3) how those opinions relate to the Justice's earlier opinions on similar topics; and (4) whether and how judicial restraint can explain those opinions.

180. See John A. Ferejohn \& Larry D. Kramer, Independent Judges, Dependent Judiciary: Institutionalizing Judicial Restraint, 77 N.Y.U. L. REV. 962, 1004-11 (2002); see also Massachusetts v. Mellon, 262 U.S. 447, 488-89 (1923); Fairchild v. Hughes, 258 U.S. 126, 129-30 (1922).

181. This Article comments on the Court's—and individual Justices'-approach to judicial restraint only in the context of Article III case law. Judicial restraint in other substantive contexts is beyond the scope of this Article. 
A group of six Justices agreed on the outcome in Patchak, Oil States, and Gill: Thomas, Ginsburg, Breyer, Alito, Kagan, and Sotomayor. Of those six, only three agreed completely on the reasoning in all three cases: Breyer, Alito, and Kagan. ${ }^{182}$

\section{A. Justice Alito}

As mentioned, Justice Alito is one of only three Justices, along with Justices Breyer and Kagan, who agreed with both the outcome and the primary reasoning in all three of the Court's Article III cases of the October 2017 Term. He joined in both Justice Thomas's plurality opinion in Patchak and majority opinion in Oil States; he joined in Chief Justice Roberts's essentially unanimous opinion in Gill. And he did so without joining in any other separate opinions. Alito is, in fact, the only Justice to vote with the majority or plurality opinion in each case without also writing separately in any. He did not author an opinion in any of the three cases, a distinction shared only by Justice Kennedy. Every other Justice authored at least one opinion in at least one of the Court's October 2017 Term Article III cases.

In each of the three cases, then, Alito aligns completely with the Court's holdings, without reservation or addition. His jurisprudence acts as a perfect proxy for the Court around which to explain the Court's general adherence - as a body - to the principle of judicial restraint.

Because Alito's personal jurisprudence coterminously overlaps with the Court's jurisprudence in Patchak, Oil States, and Gill, it is also fair to describe that personal jurisprudence as imbued with judicial restraint. This observation is consistent with his votes in several major Article III cases over the past decade, including Wellness International Network $v$. Sharif, in which he voted on the side of no Article III violation; ${ }^{183}$ Bank Markazi, in which he voted on the side of no Article III violation; ${ }^{184}$ Spokeo, Inc. v. Robins and Clapper v. Amnesty International USA, in which he voted on the side of denying standing: ${ }^{185}$ and Town of Chester $v$. Laroe Estates, in which he voted to require a showing of standing. ${ }^{186}$ One notable exception is his vote in Stern v. Marshall, in which he joined the majority in holding that non-Article III bankruptcy courts lacked authority to conclusively decide private rights. ${ }^{187}$

182. Justice Thomas in Gill did not join in the majority opinion's final section about remand, instead writing separately to concur in the judgment. Gill v. Whitford, $138 \mathrm{~S}$. Ct. 1916, 1941 (2018) (Thomas, J., concurring). Justices Ginsburg and Sotomayor in Patchak did not join in the plurality opinion; they concurred only in the judgment. Patchak v. Zinke, 138 S. Ct. 897, 912 (2018) (Ginsburg, J., concurring).

183. Wellness Int'l Network, Ltd. v. Sharif, 135 S. Ct. 1932, 1938, 1945, 1947 (2015).

184. Bank Markazi v. Peterson, 136 S. Ct. 1310, 1316-17 (2016).

185. Spokeo, Inc. v. Robins, 136 S. Ct. 1540, 1546-50 (2016) (holding that the Ninth Circuit's "standing analysis was incomplete"); Clapper v. Amnesty Int'l USA, 568 U.S. 398, 414 (2013).

186. Town of Chester v. Laroe Estates, Inc., 137 S. Ct. 1645, 1652 (2017).

187. Stern v. Marshall, 564 U.S. 462, 469, 503 (2011). 


\section{B. Justice Kagan}

Like Justice Alito, Justice Kagan agreed with both the outcome and the primary reasoning in all three of the Court's October 2017 Term Article III cases, joining in full the plurality in Patchak, the majority in Oil States, and the majority in Gill. She differed from Alito in only one respect: she authored a concurring opinion in Gill.

Kagan's Gill concurrence conspicuously reveals how she, and the other Justices who joined in her opinion, want to adjudicate a partisan-gerrymandering claim on the merits:

$[\mathrm{H}]$ ere, politicians' incentives conflict with voters' interests, leaving citizens without any political remedy for their constitutional harms. Of course, their dire need provides no warrant for courts to disregard Article III. Because of the way this suit was litigated, I agree that the plaintiffs have so far failed to establish their standing to sue, and I fully concur in the Court's opinion. But of one thing we may unfortunately be sure. Courts-and in particular this Court-will again be called on to redress extreme partisan gerrymanders. I am hopeful we will then step up to our responsibility to vindicate the Constitution against a contrary law. ${ }^{188}$

While showcasing a desire to adjudicate on the merits, the quoted passage also discloses how Kagan felt bound by standing doctrine to refrain from judicially reviewing the issue, even though she considered it "urgent."189 Kagan deftly harmonized these competing interests: her concurrence refrains from actual adjudication on standing grounds, but nevertheless provides an instruction manual for the plaintiffs to establish standing on remand, including on a thus-far neglected First Amendment theory, so that the issue of partisan gerrymandering can rise to the Court again in the near future. Her concurrence, then, can be read both as a manifesto of judicial restraint ("I want to, but I cannot") and, at the same time, a compromised version ${ }^{190}$ of that same principle.

With the possible limited exception of her concurrence in Gill, Kagan's votes fall almost perfectly in line with judicial restraint. In the two Kleinprinciple cases, Patchak ${ }^{191}$ and Bank Markazi, she voted to find no sepa-

188. Gill v. Whitford, 138 S. Ct. 1916, 1941 (2018) (Kagan, J., concurring).

189. See id.

190. Unadulterated judicial restraint would stop at "I want to, but I cannot." But the concurrence went a step further: "I want to, but I cannot; yet here's how." To that end, Justice Kagan's concurrence likely runs contrary to "judicial minimalism." See supra note 171 and accompanying text.

191. In Patchak, before voting with the plurality to hold that the Gun Lake Act "changed the law" and therefore did not violate Article III, Justice Kagan telegraphed her approach at oral argument. Beginning with the premise that it is difficult to differentiate between stripping jurisdiction and changing the law, Kagan reasoned that, even when it merely "chang[es] jurisdiction," Congress essentially "chang[es] the law." See Transcript of Oral Argument at 11, Patchak v. Zinke, 138 S. Ct. 897 (2018) (No. 16-498), 2017 WL 5159980, at *11; William D. Araiza, The Trouble with Robertson: Equal Protection, the Separation of Powers, and the Line Between Statutory Amendment and Statutory Interpretation, 48 CATH. U. L. REv. 1055, 1079 (1999). This reasoning, whatever its veracity, appears to "swallow[ ] Klein altogether," see Evan C. Zoldan, Is the Federal Judiciary Independent 
ration of powers violation. In the standing cases, Spokeo and Gill, she voted with the majorities against standing. And, in the public-rights cases, Stern, Wellness International, and Oil States, she voted consistently to reject Article III challenges. To that end, she could be regarded as a more reliable adherent to judicial restraint than even Alito, who arguably deviated from that principle in Stern.

\section{Justice Breyer}

Justice Breyer was the third of three Justices, along with Alito and Kagan, to join completely in the outcome and primary reasoning of all three cases. When viewed together-and in isolation, for that matter-these three votes display a fidelity to judicial restraint in the adjudication of Article III cases.

In Oil States, Breyer doubled down on that fidelity. To begin, he joined the majority in holding that inter partes review did not run afoul of the public-rights doctrine, a position that, as explained above, comports with notions of judicial restraint and strong deference to Congress. ${ }^{192}$ The Oil States majority made clear that its opinion spoke only about a non-Article III tribunal's authority to adjudicate public rights. ${ }^{193}$ Yet Breyer went further with a brief concurrence, in which Ginsburg and Sotomayor joined, expressly stating that the majority opinion "should not be read to say that matters involving private rights may never be adjudicated other than by Article III courts, say, sometimes by agencies."194

Breyer's views in Oil States call to mind his earlier votes in both Stern and Wellness International. In Stern, a 2011 case also dealing with the public-rights doctrine, a five-member majority held that non-Article III bankruptcy courts are constitutionally prohibited from conclusively adjudicating certain private rights. ${ }^{195}$ Breyer dissented, stressing the role of "deference" to congressional policy decisions to create non-Article III tribunals. He would have held that the Constitution does not preclude bankruptcy courts from adjudicating certain private rights. ${ }^{196}$ Then in Wellness International, Breyer joined in a majority opinion limiting Stern. ${ }^{197}$ Later, he also joined in the majority opinions in Spokeo and

of Congress?, 70 Stan. L. Rev. Online 135, 138 (2018), because "[c]hanging the law is simply how Congress acts," Bank Markazi v. Peterson, 136 S. Ct. 1310, 1335 (2016) (Roberts, C.J., dissenting). Klein, after all, involved a jurisdiction-stripping statute; yet, if "Congress 'changes the law' within the meaning of Klein whenever it passes a statute, then Klein provides no restriction at all on Congress's power to withdraw jurisdiction to decide a case." Zoldan, supra note 191, at 138. It should come as no surprise that Justice Kagan joined the majority in Bank Markazi, holding that a statute somewhat similar to the Gun Lake Act does not violate the separation of powers. See Bank Markazi, 136 S. Ct. at 1329 (majority opinion).

192. See Oil States Energy Servs., LLC v. Greene's Energy Grp., LLC, 138 S. Ct. 1365, 1375 (2018) (Breyer, J., concurring); supra notes 170-180 and accompanying text.

193. Oil States, 138 S. Ct. at 1379.

194. Id. (Breyer, J., concurring).

195. Stern v. Marshall, 564 U.S. 462, 503 (2011).

196. Id. at 519 (Breyer, J., dissenting).

197. Wellness Int'l Network, Ltd. v. Sharif, 135 S. Ct. 1932, 1942-47 (2015). 
Bank Markazi, both of which came down on the side of judicial restraint.

At the same time, just like Kagan, Breyer has also tempered his commitment to judicial restraint. For one, he joined in Kagan's Gill concurrence. ${ }^{198}$ For another, he conditioned his agreement with the Patchak plurality, writing in concurrence that he joined the plurality "on this understanding." 199 "[T]his understanding," in turn, refers to his own reading of $\S 2$ (b) of the Gun Lake Act as merely "supplement[ing]" § 2(a), which the petitioner did not challenge at the Supreme Court. ${ }^{200}$ In other words, Breyer's agreement with the plurality that the Gun Lake Act does not violate Article III apparently depended on the existence of $\S 2(a)$, which the plurality did not meaningfully take into account. At the risk of adding too many layers of speculation, Breyer might not have voted the way he did in Patchak if he had to accept the plurality opinion as-is (without the opportunity to concur).

\section{Justice Thomas}

In recent Article III cases, no other sitting Justice has adhered to judicial restraint more than Justice Thomas. Like Justice Alito, he voted with the plurality in Patchak and the majority in Oil States, without also writing separately. Thomas, in fact, authored those opinions, both of which reverentially applied the principle of judicial restraint.

In Patchak, Thomas authored the plurality opinion holding that the Gun Lake Act does not impermissibly encroach on the judiciary in violation of the separation of powers. As discussed above, this holding is consistent with the principle of judicial restraint as applied to Article III questions. ${ }^{201}$ And a closer look at the opinion underscores just how committed Thomas is to judicial restraint and deference to the Congress. To ultimately conclude that the Gun Lake Act is constitutional, Thomas and the plurality interpreted $\S 2$ (b) as a jurisdiction-stripping provision. ${ }^{202}$ As the Patchak dissent pointed out with force, however, neither the "title, headings, [n]or text of the Act" use the word "jurisdiction" or "specif[y] that the statute is jurisdictional." 203 To read the Gun Lake Act as stripping federal jurisdiction, then, is manifestly atextual. But Thomas is an avowed textualist. ${ }^{204}$ One can resolve that evident tension only by assuming that, at least for deciding the Article III issue presented in Patchak,

198. See supra notes $188-190$ and accompanying text. This tempering is itself tempered, however, by Justice Breyer's vote with the majority in Spokeo, another standing case. See Spokeo v. Robins, 136 S. Ct. 1540, 1544 (2016).

199. Patchak v. Zinke, 138 S. Ct. 897, 912 (2018) (Breyer, J., concurring).

200. Id. at $911-12$.

201. See supra note 170-180 and accompanying text.

202. Patchak, 138 S. Ct. at 905-06 (plurality opinion).

203. Id. at 918-19 (Roberts, C.J., dissenting); see supra note 69 and accompanying text.

204. See Anita S. Krishnakumar, Textualism and Statutory Precedents, 104 VA. L. Rev. 157, 161 (2018); Nancie G. Marzulla, The Textualism of Clarence Thomas: Anchoring the Supreme Court's Property Rights Jurisprudence to the Constitution, 10 AM. U. J. Gender SOC. POL'y \& L. 351, 351 (2002). 
Thomas elevated his commitment to judicial restraint above his commitment to textualism.

Then in Gill, Thomas joined in the majority opinion almost completely, but not in its entirety. Recall that the Gill majority "remand[ed] the case to the District Court so that the plaintiffs [could] have an opportunity to prove concrete and particularized injuries," a procedural move that departed from the Court's usual practice of ordering dismissal when plaintiffs fail to establish standing. ${ }^{205}$ Thomas, along with Justice Gorsuch, rejected this part of the majority opinion. In a short opinion concurring in part and concurring in the judgment, Thomas announced he would have followed the Court's "ordinary practice" and "remand[ed] the case with instructions to dismiss for lack of jurisdiction." 206 "After a year and a half of litigation in the District Court, including a 4-day trial," the plaintiffs had failed to prove standing; they should not, according to Thomas, get another chance on remand. ${ }^{207}$ His opinion in Gill, then, takes an even more judicially restrained position than does the majority: not only did the plaintiffs fail to invoke Article III power, but they should not have another opportunity to do so in the Gill lawsuit.

In sum, whether reviewing the public-rights doctrine, separation of powers under the Klein principle, or standing, Thomas votes steadfastly on the side of judicial restraint in Article III cases. ${ }^{208}$

\section{E. Justice Ginsburg}

Justice Ginsburg voted in favor of the judicially restrained outcome in all three cases. In Oil States and Gill, she joined in the majority; and in Patchak, she concurred in the judgment, offering an alternative to the plurality's reasoning for reaching the same outcome. She also joined in Justice Breyer's concurrence in Oil States and Justice Kagan's concurrence in Gill. Taking into account Ginsburg's votes in other recent Article III cases, her jurisprudence appears (mostly) internally consistent and (generally) organized around the principle of judicial restraint. She exercises greater restraint, however, in cases directly implicating deference to Congress (for example, in public-rights-doctrine and Klein principle cases) and somewhat lesser restraint in standing cases.

Ginsburg voted on the side of maximum restraint-and maximum deference to Congress-in Oil States, as well as in the two other most recent

205. Gill v. Whitford, 138 S. Ct. 1916, 1934 (2018).

206. Id. at 1941 (Thomas, J., concurring).

207. Id.

208. Other cases from recent terms confirm this trend. See Spokeo v. Robins, $136 \mathrm{~S}$. Ct. 1540, 1550 (2016) (Thomas, J., concurring); Bank Markazi v. Peterson, 136 S. Ct. 1310, 1316 (2016); Wellness Int'l Network, Ltd. v. Sharif, 135 S. Ct. 1932, 1960 (2015) (Thomas, J., dissenting); Clapper v. Amnesty Int'l USA, 568 U.S. 398, 398 (2013). But see Susan B. Anthony List v. Driehaus, 573 U.S. 149, 151 (2014) (authoring unanimous opinion holding that plaintiffs had alleged a credible threat of enforcement adequate to confer Article III standing); Stern v. Marshall, 564 U.S. 462, 469 (2011) (joining in majority opinion holding that non-Article III bankruptcy courts lacked authority to conclusively decide private rights). 
public-rights cases, Stern and Wellness International. In Oil States, not only did Ginsburg join in the majority opinion sanctioning inter partes review and rejecting an Article III challenge, but she also joined in Breyer's concurrence suggesting that Congress may even assign privaterights adjudication to non-Article III tribunals. ${ }^{209}$ Ginsburg, moreover, joined in Breyer's dissenting opinion in Stern ${ }^{210}$ and in Sotomayor's majority opinion in Wellness International, ${ }^{211}$ both of which are consistent, from a judicial-restraint perspective, with her votes in Oil States.

Despite being counted as part of the six in Patchak's 6-3 vote, Ginsburg did not vote with the plurality and, hence, did not join its reasoning directly rejecting Patchak's Article III challenge to the Gun Lake Act. ${ }^{212}$ She also did not join in Chief Justice Roberts's dissent concluding that the Act violated Article III. ${ }^{213}$ In fact, Ginsburg did not opine on Article III or the separation of powers at all. She instead concluded that the language of the Act withdrew the APA's sovereign-immunity waiver. ${ }^{214}$ Doing so permitted her to "avoid[] the separation of powers concerns raised . . . about jurisdiction stripping." 215 So, although Ginsburg did not exercise judicial restraint by applying an Article III-based rule of decision (as the plurality did), she nevertheless voted on the side of deferring to Congress and permitting the statute to stand. To that end, Ginsburg's concurrence in the judgment on sovereign-immunity grounds may fairly be characterized as an act of judicial restraint, ${ }^{216}$ especially in its "judicial minimalism" conception. ${ }^{217}$ And if one harbors doubt about Ginsburg's commitment to judicial restraint in Klein-principle cases, look to Bank

209. See supra notes $192-197$ and accompanying text.

210. Stern, 564 U.S. at 505 (Breyer, J., dissenting).

211. Wellness Int'l, 135 S. Ct. at 1938 (majority opinion).

212. See Patchak v. Zinke, 138 S. Ct. 897, 902 (2018) (plurality opinion).

213. See id. at 914 (Roberts, C.J., dissenting).

214. Id. at 913 (Ginsburg, J., concurring). This position finds support in the text of the Act:

[T] he language Congress employed in the Gun Lake Act (any "action . . . relating to the [Bradley Property] ... shall be promptly dismissed") is the mirror image of the APA's immunity waiver, which instructs that suits "against the United States" for declaratory or injunctive relief "shall not be dismissed."

Id. (alteration in original) (emphasis in original) (quoting 5 U.S.C. $\$ 702$ (2012)).

215. Id. at 914 (Sotomayor, J., concurring).

216. It is hornbook law that federal courts must address and decide subject-matter jurisdiction before proceeding to adjudicate other aspects of a case. See, e.g., Ashcroft v. Iqbal, 556 U.S. 662, 671 (2009). Justice Ginsburg would have disposed of Patchak's lawsuit on sovereign immunity grounds, without addressing the Article III question, which she (and most or all of the other Justices) understood as one of subject-matter jurisdiction. Thus, Ginsburg's opinion must be read to conceive of sovereign immunity as a jurisdictional issue. Whether sovereign immunity is, in fact, jurisdictional is a question that has split the circuits. Compare, e.g., Lors v. Dean, 746 F.3d 857, 861 (8th Cir. 2014) (quoting Harmon Indus., Inc. v. Browner, 191 F.3d 894, 903 (8th Cir. 1999)) ("[S]overeign immunity . . . is a jurisdictional threshold matter."), with Blagojevich v. Gates, 519 F.3d 370, 371 (7th Cir. 2008) ("[S]overeign immunity does not diminish a court's subject-matter jurisdiction."); see also, e.g., Sato v. Orange Cty. Dep't of Educ., 861 F.3d 923, 927 n.2 (9th Cir. 2017) ("A sovereign immunity defense is 'quasi-jurisdictional' in nature.").

217. See supra note 171 and accompanying text. 
Markazi. In that case, she authored the majority opinion upholding the statute in question, which was similar to the Gun Lake Act, on the grounds that the statute does not violate Article III or the separation of powers. $^{218}$

Although Justice Ginsburg's votes in the standing cases, Gill and Spokeo, are less judicially restrained than those in the cases already discussed, they are by no means unrestrained. It is true that in Gill, she joined in the majority opinion (as did every Justice) holding that the plaintiffs had failed to establish standing. ${ }^{219}$ But then, along with Kagan, Breyer, and Sotomayor, she joined in a concurrence providing a roadmap for the plaintiffs to show standing, a move that can be viewed as both consistent and inconsistent with judicial restraint. ${ }^{220}$ Even more starkly, Ginsburg, joined only by Sotomayor, authored a dissenting opinion in Spokeo.221 The Spokeo majority, after clarifying the proper Article III standing test, remanded the case to the Ninth Circuit to determine whether the plaintiff had established standing under this proper test. ${ }^{222}$ Ginsburg, by contrast, would have found standing even under the proper test: the plaintiff had adequately pleaded concrete harms, the type of which the statute at issue in that case was "aimed to prevent." 223 At the same time, though, she "agree[d] with much of the Court's opinion," limiting her critique to the concreteness element of standing and to the Court's decision to remand to the Ninth Circuit for further inquiry on those grounds. ${ }^{224}$ Because she voted ultimately for an exercise of Article III power, that vote cannot be classified as one of judicial restraint, at least for the purposes of this Article. That her dissent aligns fairly closely with the "judicially restrained" majority opinion, however, underscores how adjectives like "small," "nuanced," or even "strained" can sometimes aptly describe the distinction between judicial restraint and a lack of it.

\section{F. Chief Justice Roberts}

Chief Justice Roberts joined in the judgment-and fell on the side of judicial restraint—in only one of three cases: Gill. ${ }^{225}$ The Gill opinion,

218. See Bank Markazi v. Peterson, 136 S. Ct. 1310, 1317 (2016).

219. Gill v. Whitford, 138 S. Ct. 1916, 1933-34 (2018).

220. See id. at 1935-40 (Kagan, J., concurring); supra notes 170-180 and accompanying text.

221. Spokeo, Inc. v. Robins, 136 S. Ct. 1540, 1554 (2016) (Ginsburg, J., dissenting).

222. Id. at 1550 (majority opinion).

223. Id. at 1556 (Ginsburg, J., dissenting). Justice Ginsburg's and the Spokeo majority's focus on the substantive statute giving rise to the claim at issue tends to bleed what is ostensibly an Article III standing discussion into a statutory-interpretation discussion under the so-called "zone of interests" test, which asks courts to determine "whether a legislatively conferred cause of action encompasses a particular plaintiff's claim." See Lexmark Int'l, Inc. v. Static Control Components, Inc., 572 U.S. 118, 127 (2014). The zoneof-interests test is not grounded in Article III.

224. Spokeo, 136 S. Ct. at 1554-55 (Ginsburg, J., dissenting).

225. Concerns about the Court's institutional integrity likely also motivated the Chief's posture of restraint in Gill. At oral argument, he expressed grave concern about how ask- 
which Roberts authored, holds that the plaintiffs had not established standing. ${ }^{226}$ That opinion accords with Roberts's vote in the other recent standing case, Spokeo, where he joined in Justice Alito's majority opinion clarifying and limiting standing principles in a judicially restrained way. ${ }^{227}$

But the Chief Justice's alignment with judicial restraint in Article III cases ends there. His votes in Oil States and in Patchak depart from judicial restraint, and they were foreshadowed by his previous votes in similar Article III cases. Specifically, Roberts joined in Justice Gorsuch's dissent in Oil States, a public-rights doctrine case, concluding that inter partes review violated Article III and unconstitutionally encroached on judicial power. In 2011 in Stern, another public-rights doctrine case, Roberts authored the five-Justice majority opinion holding that non-Article III bankruptcy courts are limited in their authority to adjudicate (and enter final judgment on) private rights. Accepting that Congress can assign to non-Article III tribunals some public rights for adjudication, Roberts and the Stern Court refused to extend the public-rights exception to a common-law counterclaim asserted in a bankruptcy-court proceeding.228 Given this outcome, the Stern majority decided in favor of asserting (or self-defending) the judiciary's own Article III power and, hence, against judicial restraint.

Four years later, when a majority of the Court in Wellness International limited the Stern decision and held that litigants could consent to bankruptcy court adjudication of common law private rights, Roberts penned a dissent. ${ }^{229}$ Accusing the Court of "let[ting] down its guard," the Chief Justice recalled that " $[\mathrm{t}] \mathrm{he}$ Framers adopted the formal protections of Article III for good reasons." ${ }^{230} \mathrm{He}$, along with Justices Scalia and Thomas, rejected the majority's reasoning and declared, as the Court had previously, "the fact that a given law or procedure is efficient, convenient, and useful in facilitating functions of government, standing alone, will not save it if it is contrary to the Constitution." 231

In Patchak, Roberts, joined by Justices Gorsuch and Kennedy (and, in limited principle, Justice Sotomayor), ${ }^{232}$ dissented from the Court's judg-

ing the Court to pick between political winners and losers threatens the Court's legitimacy in the public eye. See Transcript of Oral Argument at 37-40, Gill v. Whitford, $138 \mathrm{~S}$. Ct. 1916 (2018) (No. 16-1161), 2017 WL 4517131, at *37-40. See generally Cass R. Sunstein, Unanimity and Disagreement on the Supreme Court, 100 CoRnell L. Rev. 769 (2015); Jeffrey Rosen, Roberts's Rules, Atrantic, Jan.-Feb. 2007, http://www.theatlantic.com/ magazine/archive/2007/01/robertss-rules/305559/ [https://perma.cc/2P2L-H5MY]. Disposing of Gill on standing grounds allayed those concerns-somewhat.

226. Gill, 138 S. Ct. at 1923.

227. See Spokeo, 136 S. Ct. at 1547-50 (majority opinion).

228. Stern v. Marshall, 564 U.S. 462, 487-88 (2011).

229. Wellness Int'l Network, Ltd. v. Sharif, 135 S. Ct. 1932, 1950 (2015) (Roberts, C.J., dissenting).

230. Id.

231. Id. (quoting INS v. Chadha, 462 U.S. 919, 944 (1983)). Justice Gorsuch followed similarly in his Oil States dissent. See Oil States Energy Servs., LLC v. Greene's Energy Grp., LLC, 138 S. Ct. 1365, 1380 (2018) (Gorsuch, J., dissenting).

232. See infra notes $275-285$ and accompanying text. 
ment upholding the Gun Lake Act. His dissent, relying heavily on abstract separation of powers principles (as manifested most pointedly in Klein), would have held that Congress's directive to dismiss suits related to the Bradley Property violated Article III. ${ }^{233}$ As Professor Evan Zoldan summarized, "[a] statute eliminating a federal claim in a pending case appears to be doing more than merely making law; instead, it appears to be deciding a federal case." 234 For Roberts, ruling as the majority did risks endowing Congress with "plenary authority to insulate itself from separation of powers arguments." 235

Chief Justice Roberts appears to have drawn much of his Patchak dissent from his dissent in Bank Markazi. ${ }^{236}$ The Bank Markazi Court held that the Iran Threat Reduction and Syria Human Rights Act of 2012, which prescribed a new rule of decision for a very narrow set of pending cases, does not violate separation of powers principles. ${ }^{237}$ Roberts, joined by Justice Sotomayor, objected to what they viewed as the Court's disregard of Klein. Whereas the Court dismissed Klein as "puzzling" and its progeny as lacking teeth, ${ }^{238}$ Roberts wrote at length about Klein and its enduring import. ${ }^{239}$ The Chief Justice would have held that the statute in Bank Markazi was sufficiently similar to the statute struck down in Klein, such that it should fall on Article III grounds, too. Roberts's vote and reasoning in Bank Markazi presaged his vote and reasoning in Patchak, where Congress had gone "much further" with the Gun Lake Act than it had with the statute in Bank Markazi.240

Roberts's Article III decisions are undoubtedly consistent over time, at least when viewed in their respective doctrinal silos of the Klein principle, public rights, and standing. But does brushing aside those silos betray significant internal inconsistency? After all, Roberts's votes in the Kleinprinciple cases (Patchak and Bank Markazi) and the public-rights cases (Oil States, Wellness International, and Stern) all come down on the side of asserting Article III power; but his votes in the standing cases (Gill and Spokeo) come down on the side of not asserting that power. When viewed through the lens of judicial restraint, then, Roberts's votes on Article III issues indeed appear inconsistent. ${ }^{241}$

233. See Patchak v. Zinke, 138 S. Ct. 897, 921-22 (2018) (Roberts, C.J., dissenting).

234. Zoldan, supra note 191, at 135-36.

235. Transcript of Oral Argument, supra note 191, at 32.

236. Compare Patchak, 138 S. Ct. at 914-22 (Roberts, C.J., dissenting), with Bank Markazi v. Peterson, 136 S. Ct. 1310, 1329-35 (2016) (Roberts, C.J., dissenting).

237. Bank Markazi, 136 S. Ct. at 1325-29 (majority opinion).

238. Id. at 1323 (quoting Daniel J. Meltzer, Congress, Courts, and Constitutional Remedies, 86 Geo. L.J. 2537, 2538 (1998)).

239. Id. at 1333-35 (Roberts, C.J., dissenting).

240. See Patchak, 138 S. Ct. at 918 (Roberts, C.J., dissenting).

241. Of the Justices chronicled thus far, the Chief Justice is the first to assert judicial power (and shun judicial restraint) more often than not, at least as the term "judicial restraint" is used in this Article.

Roberts testified at his confirmation hearing about the importance of, and his fidelity to, judicial restraint. Confirmation Hearing on the Nomination of John G. Roberts, Jr. to Be Chief Justice of the United States: Hearing Before the S. Comm. On the Judiciary, 109th Cong. 158 (2005) (statement of John G. Roberts, Jr., Nominee, Chief Justice of the United 
Setting aside judicial restraint for a moment, there is at least one way to harmonize Roberts's Article III jurisprudence. Although it may not follow the Court's institutional tendency to coalesce around the principle of judicial restraint, Roberts's own organizing principle in Article III cases is no less cogent, coherent, or principled.

More than any other sitting Justice, Chief Justice Roberts cares about preserving judicial independence and self-defending the judicial branch against encroachment by legislative and executive branches. ${ }^{242}$ Consistent votes and eloquent writing in Stern, Wellness International, Bank Markazi, Patchak, and Oil States all typify and reinforce this conclusion. When judicial power comes under attack, Roberts appears wholly unmotivated by judicial restraint, seeking instead to safeguard his own domain. 243 The five cases listed above in this paragraph all include separation of powers questions that involve arguable encroachment against the judicial branch.

Standing doctrine, too, is about separation of powers. ${ }^{244}$ It concerns itself not with encroachment against the judicial branch, but rather by the judicial branch. "The law of Article III standing, which is built on separation of powers principles, serves to prevent the judicial process from being used to usurp the powers of the political branches." 245 The Court's standing inquiry, indeed, "has been especially rigorous when reaching the merits of the dispute would force [it] to decide whether an action taken by one of the other two branches of the Federal Government was unconstitutional." 246 To that end, "[r]elaxation of standing requirements is directly related to the expansion of judicial power." 247 Unlike in the publicrights doctrine cases and the Klein-principle cases, the separation of powers concern in standing cases guards against potential encroachment on the legislative branch; without a properly conceived and enforced standing doctrine, the theory goes, the judiciary risks taking action that smacks of legislative power. By voting against exercising judicial power in stand-

States Supreme Court). His statements, however, tended to fall more in line with the "judicial minimalism" conception of judicial restraint than with the constitutional-restraint conception used in this Article. See supra notes 170-180 and accompanying text.

Roberts's departures from judicial restraint, for better or for worse, have not gone unnoticed. Justice Scalia, for example, once described Roberts as exercising "faux judicial restraint" amounting to "judicial obfuscation." FEC v. Wisc. Right to Life, Inc., 551 U.S. 449, 498 n.7 (2007) (Scalia, J., concurring); see Rosen, supra note 170, at 129.

242. Although the sample size is too small to confidently draw a conclusion, Justice Gorsuch has voted with Chief Justice Roberts both times this question was placed before him in his short tenure-namely, in Patchak and Oil States.

243. Assume, though, that Roberts's motives go beyond mere parochial self-interest. See Oil States Energy Servs., LLC v. Greene's Energy Grp., LLC, 138 S. Ct. 1365, 1386 (2018) (Gorsuch, J., dissenting).

244. See supra note 162 and accompanying text.

245. Susan B. Anthony List v. Driehaus, 573 U.S. 149, 157 (2014) (quoting Clapper v. Amnesty Int'l USA, 568 U.S. 398, 408 (2013)).

246. Clapper, 568 U.S. at 408 (quoting Raines v. Byrd, 521 U.S. 811, 819-20 (1997)).

247. Id. at 408-09 (quoting United States v. Richardson, 418 U.S. 166, 188 (1974) (Powell, J., concurring)). 
ing cases, as he has, Roberts is voting to protect the legislative branch against encroachment by the judicial branch.

Therein lies the harmony in the Chief Justice's Article III jurisprudence: when a separation of powers concern comes before the Court, Roberts consistently votes to defend the separation of powers and to ensure stark divisions between the three branches. In other words, in separation of powers cases, including the three Article III cases highlighted in this article, Roberts votes to err on the side of protecting from encroachment the branch arguably being encroached upon, irrespective of which branch that is. To that end, in standing cases like Gill, he tends to exercise judicial restraint, because the threat of encroachment emanates from the judiciary unto Congress; ${ }^{248}$ but in public-rights cases like Oil States and in Klein-principle cases like Patchak, he tends to assert judicial power, because the threat of encroachment advances in the opposite direction. In short, in Article III cases, the Chief Justice elevates the principle of protecting the separation of powers above any principle of judicial restraint. ${ }^{249}$

\section{G. Justice Gorsuch}

As explained above, Chief Justice Roberts has steadfastly voted to protect the independence of the judicial branch against encroachment. Justice Gorsuch now appears to be joining Roberts as a consistent, resolute defender of judicial independence, as indicated by his votes in Patchak and Oil States. Also like the Chief Justice, Gorsuch exercises judicial restraint in standing cases. Gorsuch, in fact, voted with Roberts in all three cases, save for the section of Gill granting remand: he joined in Roberts's Patchak dissent; he authored a dissent in Oil States, in which Roberts was the only other member of the Court to join; and he joined in Roberts's Gill majority opinion in substantial part, except for the final section granting remand. ${ }^{250}$ Thus, much of what was said above about Roberts applies to Gorsuch, too. Although the sample size is small-because of how recently he joined the Court, it is not possible to look to his behavior in Stern, Bank Markazi, or any other relevant case before Patchak-the existing evidence portends a second Chief Justice Roberts in the making.

248. See also, e.g., Nat'l Fed'n of Indep. Bus. v. Sebelius, 567 U.S. 519, 538 (2012) (exercising judicial restraint to uphold constitutionality of the Affordable Care Act and asserting that "[i]t is not our job to protect the people from the consequences of their political choices"). See generally Jonathan H. Adler, Standing Still in the Roberts Court, 59 CASE W. REs. L. Rev. 1061 (2009).

249. This leads to another question: If Chief Justice Roberts's votes are consistent when viewed through the lens of separation of powers principles but inconsistent when viewed through the lens of judicial restraint, then are Justices' votes that are consistent when viewed through a lens of judicial restraint inconsistent when viewed through a lens of separation of powers? Put simply, is it ever possible to completely harmonize principles of separation of powers with those of judicial restraint, at least as the term "judicial restraint" is used in this Article?

250. Justice Gorsuch joined in Justice Thomas's opinion concurring in part and concurring in the judgment. Gill v. Whitford, 138 S. Ct. 1916, 1941 (2018) (Thomas, J., concurring). 
Further, not only did Gorsuch join Roberts in dissent in Oil States, he authored that dissent. ${ }^{251}$ That opinion draws heavily from Roberts's opinions, majority and dissenting, in other cases. For instance, much of the content, structure, and theme of Roberts's Stern majority opinion finds its way into Justice Gorsuch's Oil States dissent. ${ }^{252}$ Gorsuch, moreover, opens his opinion with a rhetorical hypothetical, just as Roberts did in his Bank Markazi dissent. ${ }^{253}$ Both Justices also have relied heavily on Founding Era history. In his Patchak dissent, Roberts wrote at length about colonial legislatures sitting as courts of equity and how the Constitution was structured to avoid that practice. ${ }^{254}$ Dissenting in Oil States, Gorsuch emphasized how the executive branch exercises complete control over the Patent Trial and Appeal Board, not unlike how the despised adjudicatory bodies of the Founding Era were entirely under the control of the Crown. ${ }^{255}$ Thus, Gorsuch viewed inter partes review as a threat to the promise of judicial independence enshrined in the Constitution. ${ }^{256} \mathrm{He}$ also quoted Roberts's dissent in Bank Markazi: “The people's historic rights to have independent judges decide their disputes with the government should not be a 'constitutional Maginot Line, easily circumvented' by such 'simpl[e] maneuver[s].'" 257

Finally, Gorsuch was the only Justice in any of the three cases to expressly address judicial restraint. In that regard, his words confirm his recognition of, and alignment with, Roberts's heightened awareness of separation of powers and judicial-independence concerns:

Today's decision may not represent a rout but it at least signals a retreat from Article III's guarantees. Ceding to the political branches ground they wish to take in the name of efficient government may seem like an act of judicial restraint. But enforcing Article III isn't about protecting judicial authority for its own sake. It's about ensuring the people today and tomorrow enjoy no fewer rights against governmental intrusion than those who came before. And the loss of the right to an independent judge is never a small thing. It's for that reason Hamilton warned the judiciary to take "all possible care . . . to defend itself against" intrusions by the other branches. ${ }^{258}$

251. Oil States Energy Servs., LLC v. Greene's Energy Grp., LLC, 138 S. Ct. 1365, 1379 (2018) (Gorsuch, J., dissenting).

252. Compare Stern v. Marshall, 564 U.S. 462, 468-70 (2011), with Oil States, 138 S. Ct. at 1380 . Justice Gorsuch also quotes from Stern and many cases on which Stern relied. See Oil States, 138 S. Ct. at 1381 (quoting Stern, 564 U.S. at 484).

253. Compare Oil States, 138 S. Ct. at 1379, with Bank Markazi v. Peterson, 136 S. Ct. 1310, 1329 (2015) (Roberts, C.J., dissenting).

254. See Patchak v. Zinke, 138 S. Ct. 897, 914-15 (2018) (Roberts, C.J., dissenting).

255. See Oil States, 136 S. Ct. at 1380-81 (Gorsuch, J., dissenting).

256. Id. at $1379,1381$.

257. Id. at 1385-86 (alteration in original) (quoting Bank Markazi, 136 S. Ct. at 1335 (Roberts, C.J., dissenting)).

258. Id. (quoting The Federalist No. 78, at 466 (Alexander Hamilton) (Clinton Rossiter ed., 1961)). 


\section{H. Justice Sotomayor}

Justice Sotomayor's votes in Article III cases follow an interesting, and sometimes seemingly inconsistent, jurisprudential pattern. In Gill, Sotomayor joined the essentially unanimous majority opinion in full, holding that the plaintiffs had not (yet) established Article III standing. At first blush, this vote may seem inconsistent with her views in other standing cases, in which she has exhibited a lenient approach to standing. In Spokeo, for example, the Court held that the Ninth Circuit had failed to apply a complete and rigorous standing test. 259 Joining Justice Ginsburg in dissent, Sotomayor would have held that the plaintiff had established standing. ${ }^{260}$

Yet there is nothing inherently inconsistent between Sotomayor's approach in Spokeo and her approach in Gill. For one, she joined in Justice Kagan's Gill concurrence, providing the plaintiffs with a roadmap to follow to establish Article III standing on remand. ${ }^{261}$ And, importantly, the Gill majority departed from the "usual" practice of dismissing a case when plaintiffs fail to establish standing, instead remanding to give them a second chance. ${ }^{262}$ Given the language of Kagan's concurrence, which in some places expresses yearning to adjudicate a partisan-gerrymandering claim on the merits, ${ }^{263}$ it is not difficult to imagine that the Court was only able to achieve its near-consensus by including the remand order. In that way, then, Sotomayor's decision to join in the majority appears both pragmatic and unsurprising. And it is entirely in harmony with her prior standing jurisprudence.

What is somewhat more beclouded, however, is Sotomayor's approach to other Article III and separation of powers issues. At one extreme, consider her views in Oil States. She joined the majority in holding that inter partes review was permitted under the public-rights doctrine and consistent with the separation of powers. ${ }^{264}$ This position, as explained above, comports with notions of judicial restraint and strong deference to Congress. ${ }^{265}$ In its opinion, the Oil States majority made clear that the decision only answered questions about a non-Article III tribunal's authority to adjudicate public rights. ${ }^{266}$ Yet Sotomayor went further, joining in Justice Breyer's brief concurrence along with Justice Ginsburg, which states that the majority opinion "should not be read to say that matters involving private rights may never be adjudicated other than by Article III

259. See Spokeo, Inc. v. Robins, 136 S. Ct. 1540, 1550 (2016).

260. Id. at 1555 (Ginsburg, J., dissenting).

261. See Gill v. Whitford, 138 S. Ct. 1916, 1934-40 (2018) (Kagan, J., concurring).

262. Id. at $1933-34$ (majority opinion).

263. See, e.g., id. at 1941 (Kagan, J., concurring) ("Courts-and in particular this Court-will again be called on to redress extreme partisan gerrymanders. I am hopeful we will then step up to our responsibility to vindicate the Constitution against a contrary law.").

264. Oil States Energy Servs., LLC v. Greene's Energy Grp., LLC, 138 S. Ct. 1365, 1375 (2018).

265. See supra notes 170-180 and accompanying text.

266. See Oil States, 138 S. Ct. at 1379. 
courts, say, sometimes by agencies."267

Sotomayor's views in Oil States comport with her earlier views in the public-rights doctrine cases-Stern and Wellness International. In Stern, recall, a five-member majority held that non-Article III bankruptcy courts are constitutionally prohibited from adjudicating certain private rights. ${ }^{268}$ Sotomayor joined in a dissenting opinion in that case, again authored by Breyer. ${ }^{269}$ Stressing the role of "deference" to congressional policy decisions to create non-Article III tribunals, the dissent would have held that the Constitution does not preclude bankruptcy courts from conclusively adjudicating certain private rights. ${ }^{270}$ Then, in 2015, Sotomayor turned the tables in Wellness International, authoring a majority opinion that curbed Stern's effect. Over a four-member dissent, the Court held that it is constitutionally permissible for a bankruptcy court to conclusively adjudicate private rights with the parties' knowing and voluntary consent. ${ }^{271}$ Sotomayor's positions in these public-rights doctrine cases are marked by judicial restraint and deference to the legislative branch.

At the other extreme, consider Sotomayor's views in Bank Markazi. Recall that in Bank Markazi, decided in 2016, a majority of the Court held that a statute that prescribed new rules of decision for a very narrow class of pending cases did not offend the separation of powers. ${ }^{272}$ Chief Justice Roberts dissented, arguing that the statute impermissibly encroached on independent judicial power. ${ }^{273}$ Sotomayor was the only other member of the Court to join Roberts in dissent.

This vote, which aligns with Roberts's and Gorsuch's approach to the separation of powers as described above, ${ }^{274}$ is not one marked by judicial restraint, but rather by an assertion and self-defense of judicial power and independence. Although perhaps somewhat consistent with her approach in Gill (in which she, despite denying standing, joined in a concurring opinion outlining the steps to take to permit a federal court to exercise Article III power), Sotomayor's Bank Markazi vote nevertheless conflicts with her restrained, deferential positions in Oil States, Stern, and Wellness International.

With her Bank Markazi vote in mind, consider Sotomayor's views in Patchak, about which several things are worth discussing. First, splitting from some familiar friends in Oil States, Stern, and Wellness International, Sotomayor chose not to join a plurality that blessed the Gun Lake Act as constitutionally permissible under Article III. Second, she also did not

267. Id. (Breyer, J., concurring).

268. Stern v. Marshall, 564 U.S. 462, 503 (2011).

269. Id. at 505-21 (Breyer, J., dissenting).

270. Id. at 519 .

271. Wellness Int'l Network, Ltd. v. Sharif, 135 S. Ct. 1932, 1944-45 (2015).

272. Bank Markazi v. Peterson, 136 S. Ct. 1310, 1325 (2016).

273. Id. at 1329 (Roberts, C.J., dissenting); see supra notes 236-240 and accompanying text.

274. See supra notes 253-258 and accompanying text. 
join in Roberts's dissenting opinion, which would have held that the Gun Lake Act violated the separation of powers. Third, she wrote separately to stress her agreement with the dissent's approach to the separation of powers question:

I agree with the dissent that Congress may not achieve through jurisdiction stripping what it cannot permissibly achieve outright, namely, directing entry of judgment for a particular party. I also agree that an Act that merely deprives federal courts of jurisdiction over a single proceeding is not enough to be considered a change in the law and that any statute that portends to do so should be viewed with great skepticism. ${ }^{275}$

Fourth, she ultimately voted to concur in the judgment, joining in Ginsburg's opinion affirming the constitutionality of the Gun Lake Act by applying a rule of decision grounded in sovereign-immunity law and sidestepped the separation of powers question altogether. ${ }^{276}$ Notably, Sotomayor's vote to join Ginsburg was not required to create a five-member bloc in favor of upholding the Act. She could have, for instance, joined in the dissent without altering the judgment in the case.

Sotomayor's vote in Patchak may reconcile her otherwise ostensibly inconsistent positions between exercising judicial restraint and asserting judicial power. On the one hand, her vote with Ginsburg to uphold the Gun Lake Act allowed her to remain consistent with her restrained, deferential positions in Oil States, Stern, and Wellness International. At the same time, voting to so uphold on non-Article III grounds also allowed her to pen a separate concurrence agreeing with Roberts's less restrained and less deferential dissenting opinion that was more consistent with her position in Bank Markazi.

Still, though, there are things this reconciliation cannot account for. It strikes one as odd, first of all, that Sotomayor took a hard line in Bank Markazi by joining in a dissent that would have struck down a statute as unconstitutional in violation of the separation of powers, but then in Patchak, when a similar statute arguably went further than the statute in Bank Markazi ${ }^{277}$ she joined a line of reasoning that upheld the statute, even when doing so was unnecessary to form a majority. The only apparent difference is that in Patchak, the plaintiff brought the suit directly against the government under the Administrative Procedure Act. She affirmed as much at oral argument: "I think there is something fundamentally different about suits involving the government because sovereign immunity or any suit against the government is a matter only of largesse and the government's voluntary choice."278

Moreover, in Patchak, while Sotomayor agreed with the Chief Justice's

275. Patchak v. Zinke, 138 S. Ct. 897, 913 (2018) (Sotomayor, J., concurring).

276. Id. at 912 (Ginsburg, J., concurring).

277. See id. at 918 (Roberts, C.J., dissenting).

278. Transcript of Oral Argument, supra note 191, at 19. 
reasoning in dissent, ${ }^{279}$ she then went on to say, "I differ with the dissent's ultimate conclusion only because, as Justice Ginsburg explains, the [Gun Lake Act] should not be read to strip the federal courts of jurisdiction but rather to restore the Federal Government's sovereign immunity." 280 But this statement creates a conundrum. Thomas's plurality opinion depends on the notion that the Gun Lake Act is a jurisdictionstripping statute. ${ }^{281}$ Roberts's dissent, by contrast, vehemently asserts that Gun Lake Act is not a jurisdiction-stripping statute. ${ }^{282}$ If the Act "should not be read to strip," 283 as Justice Sotomayor writes, doesn't that mean she agrees with the dissent that there are separation of powers concerns with the Act? After all, the Gun Lake Act is either a jurisdictionstripping statute or it is not. Her opinions in Patchak, then, must be read as carving out an exception to the dissent's reasoning for cases when the defendant is the government.

On the one hand, by agreeing with the Patchak dissent in principle, Sotomayor at least implied that the Gun Lake Act violates the separation of powers. On the other hand, she voted to decide the case on sovereignimmunity grounds. This dualism effectively tolerates the legislative branch (and executive branch) taking action that violates the separation of powers (a limitation on action), so long as that action finds support in a different constitutional grant of authority. But this turns constitutional law and judicial review on its head. Normally, if the Constitution grants Congress the authority to pass particular legislation, but that legislation runs afoul of a constitutional limitation on authority, then that legislation is unconstitutional. The Court will not sustain, for example, an act supported by the Commerce Power if it also violates the Equal Protection Clause. ${ }^{284}$

\section{CONCLUSION}

As a function of constitutional structure, the U.S. Supreme Court occupies the unique position of being the ultimate interpreter of its own constitutional power. These interpretations manifest in cases interpreting Article III. In such cases, distilled to their most basic level, the Court can either decide to assert judicial power or to not assert judicial power. Not asserting judicial power in an Article III case can fairly be characterized as exercising judicial restraint.

279. Patchak, 138 S. Ct. at 913 (Sotomayor, J., concurring).

280. Id. at 913 (emphasis added) (citations omitted).

281. See id. at 905-06 (plurality opinion).

282. See id. at 917-21 (Roberts, C.J., dissenting).

283. Id. at 913 (Sotomayor, J., concurring).

284. National Federation of Independent Business v. Sebelius is not to the contrary. See Nat'l Fed'n of Indep. Bus. v. Sebelius, 567 U.S. 519, 588 (2012). In that case, the Court upheld the Affordable Care Act as a permissible exercise of the Tax Power. Id. at 575. At the same time, the Court held that the Commerce Clause did not provide support for the Act. Id. at 560. The Court did not, by contrast, hold that the Act violated any limitation on Congressional power. See id. 
During the October 2017 Term, the Court decided three cases in which the interpretation of Article III was integral to the outcome: Patchak, Oil States, and Gill. Each of those cases implicated a distinct doctrine of Article III jurisprudence: the Klein principle, the public-rights doctrine, and standing, respectively.

Even though Patchak, Oil States, and Gill each involved different doctrinal principles, all three cases nevertheless commanded a majority of Justices who voted on the side of exercising judicial restraint. In Patchak, proceeding on two separate lines of reasoning, a multi-opinion majority of the Court held that the Gun Lake Act, which effectively decided a pending case, did not violate Article III. In Oil States, the Court held that inter partes review, under which non-Article III tribunals could conclusively adjudicate patent validity, did not violate Article III. And in Gill, the Court decided that the plaintiffs had not established standing, and hence, the federal judiciary could not exercise its Article III power. In each case, the judicial branch had a choice to either assert its own Article III power or to refrain from doing so and defer to the other branches. In each case, a majority of the Court chose the latter path.

Across the three 2017 cases, and in other cases from recent terms, the Justices have revealed their own individual approaches to Article III issues. These approaches both describe past behavior and, in a limited way, prognosticate future behavior in similar cases. Irrespective of whether or how they exercise judicial restraint in non-Article III cases, several Justices-particularly Justices Thomas and Alito, as well as Justices Ginsburg, Breyer, and Kagan-consistently vote on the side of exercising judicial restraint in Article III cases. To a greater or lesser degree, these Justices will likely continue to favor judicial restraint in Article III cases.

Chief Justice Roberts and Justice Gorsuch, by contrast, exercise judicial restraint only in those Article III cases that present a threat of encroachment emanating from the judicial branch toward another branch, including cases decided on standing grounds. In other Article III cases, when the threat of encroachment flows from another branch toward the judicial branch, including Klein-principle and public-rights doctrine cases, Roberts and Gorsuch reside firmly on the side of asserting judicial power and self-defending judicial independence. For these two, ensuring a robust separation of powers exceeds any commitment to judicial restraint.

Justice Sotomayor defies classification. She voted on the side of exercising judicial restraint in all three of the 2017 cases. But she also has dropped significant breadcrumbs-her solo concurrence in the judgment in Patchak and her dissenting vote in Bank Markazi, to name but twothat point in the opposite direction. She may prove to be a "swing vote" in future Article III cases. ${ }^{285}$

285. Justice Kennedy, now since retired, also participated in all three 2017 Article III cases. He joined in the majority opinions (and no separate opinions) in Oil States and Gill, both of which came down on the side of judicial restraint. At the same time, he joined in the dissent in Patchak, which ruled on the side of asserting Article III power. This vote in a 
All told, even considering Chief Justice Roberts and Justice Gorsuch, the potential swing vote of Justice Sotomayor, and the unknowns of Justice Kavanaugh, there are still five Justices who reliably vote in Article III cases on the side of exercising judicial restraint. Just as importantly, it is in these same cases when some of those five have departed from judicial restraint-for example, in Spokeo or the Gill concurrence-that Chief Justice Roberts and Justice Gorsuch have been most open to exercising restraint. ${ }^{286}$ To that end, judicial restraint looks poised to hold its position for the foreseeable future as a unifying principle in cases where the Court's interpretation of Article III is outcome-determinative.

Klein-principle case marks a change from his vote with the majority in Bank Markazi to uphold the statute in question in the face of a separation of powers challenge similar to that in Patchak.

286. Sometimes, after all, upholding the separation of powers and exercising judicial restraint lead to the same conclusion. They are not necessarily at odds, as the standing cases show. 